\title{
The prevalence of HIV among MSM in China: a large-scale systematic analysis
}

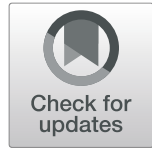

\author{
Meng-Jie Dong ${ }^{1 *}\left(\mathbb{D}\right.$, Bin Peng ${ }^{2}$, Zhen-Feng Liu', Qian-ni Ye ${ }^{1}$, Hao Liu', Xi-Li Lu', Bo Zhang ${ }^{1}$ and Jia-Jia Chen ${ }^{3}$
}

\begin{abstract}
Background: The prevalence of HIV among men who have sex with men (MSM) has become a significant public health challenge. The aim was to comprehensively estimate the national prevalence of HIV among MSM and its time trends through a large-scale systematic analysis.

Methods: Systematic search of Cochrane Library, PubMed, EMBASE, CNKI, VIP, and Wanfang Data databases without language restriction for studies on the prevalence of HIV among MSM published before Dec.31, 2018. Studies were eligible for inclusion if they were published in the peer-reviewed literature and used validated assessment methods to assess the prevalence of HIV among MSM. Estimates were pooled using random-effects analysis.

Results: Data were extracted from 355 cross-sectional studies (571,328 individuals) covered 59 cities from 30 provinces and municipalities of China. The overall national prevalence of HIV among MSM from 2001 to 2018 was estimated to be $5.7 \%$ (95\% Cl: 5.4-6.1\%), with high between-study heterogeneity $\left(I^{2}=98.0 \%, P<0.001\right)$. Our study showed an increased tendency in the HIV prevalence as time progressed by meta-regression analysis $\left(R^{2}=95.9 \%\right.$, $P<0.0001)$. HIV prevalence was the highest in those aged 50 years and older with HIV prevalence of 19.3\% (95\% Cl: $13.1-27.4 \%, N=13)$. HIV was more prevalent in the illiterate population $(16.8 \%)$, than in those who had received an education. Although the internet was a major venue for Chinese MSM seeking male sex partners (35.6, 95\%Cl: 32.3$39.9 \%, N=101)$, seeking MSM in bathhouses/saunas had the highest associated prevalence of HIV $(13.4,95 \% \mathrm{Cl}$ : 10.3-17.1\%, N =22). The HIV prevalence among MSM varied by location: compared with other regions in China, HIV was highly prevalent among MSM in the southwest $(10.7,95 \% \mathrm{Cl}: 9.3-12.2 \%, N=91)$. Compared to participants who sometimes or always used condoms, participants who had never used a condom in the past 6 months had a higher risk of HIV infection, with odds ratios of 0.1 (95\% Cl: 0.08-0.14).
\end{abstract}

Conclusions: Our analysis provided reliable estimates of China's HIV burden among MSM, which appears to present an increasing national public health challenge. Effective government responses are needed to address this challenge and include the implementation of HIV prevention.

Keywords: Prevalence, MSM, HIV, Systematic analysis, China

\section{Background}

Since the late 1990s, increasing numbers of men who have sex with men (MSM) have been diagnosed with HIV in the majority of countries with large and visible MSM communities [1-3]. Chinese scientists began studying HIV-related risk behaviours among MSM in 1993, but epidemiological studies assessing the prevalence of HIV were not conducted until 2000 [2]. A growing body of evidence from different time periods and

\footnotetext{
* Correspondence: dmjlzf2016@zju.edu.cn

'The Department of Nuclear Medicine, The First Affiliated Hospital, College of Medicine, Zhejiang University, Zhejiang 310003, People's Republic of China Full list of author information is available at the end of the article
}

locations has shown that MSM play an increasingly important role in China's HIV/AIDS epidemic. A report by the Chinese Ministry of Health estimated that approximately 780,000 people were estimated to be living with HIV/AIDS in China in 2011, and $17.4 \%$ of the estimated HIV/AIDS cases were attributable to male-to-male sexual contact [3]. Recent national reports showed that HIV transmission among MSM accounted for 21.4 to $23.4 \%$ of the newly identified HIV/AIDS cases in some areas in China $[2,4,5]$.

Estimates of the overall HIV prevalence among MSM in China have relied on several different reviews which

(C) The Author(s). 2019 Open Access This article is distributed under the terms of the Creative Commons Attribution 4.0 International License (http://creativecommons.org/licenses/by/4.0/), which permits unrestricted use, distribution, and 
conducted from 2001 to 2009 [6], 2003 to 2009 [7], and 2005 to 2010 [8]; these reviews found that MSM formed a high-risk population for HIV infection in China, with an overall prevalence ranging from 2.5 to $6.5 \%$. Furthermore, these reviews identified a rising trend in the national HIV prevalence, with an estimated $0.9 \%$ increase in HIV infection among MSM in China from 2003 to 2008 [3, 6-9]. However, our understanding of the nationwide HIV epidemiology remains incomplete. A wide range of demographic, behavioural, and societal factors that predict HIV acquisition among MSM in China have been identified. However, to the best of our knowledge, the relationships between these factors (including age, education, sex partners, commercial sex, and unprotected sexual intercourse) and the prevalence of HIV infection among MSM have not been reported based on all available data from China.

An accurate understanding of the HIV prevalence among MSM is critical for tailoring interventions and evaluating previously established programmes and services. The purpose of this study was to perform a largescale systematic analysis to examine HIV epidemiology among MSM in China based on studies published up to Dec.2018.

\section{Methods}

\section{Search strategy}

A comprehensive literature search was conducted in the following databases to identify studies published up to Dec.31, 2018: Cochrane Library, PubMed, EMBASE, Chinese National Knowledge Infrastructure (CNKI), VIP, and Wanfang Data. Two independent investigators performed the searches in parallel. We used combinations of keywords and medical subject heading (MESH) terms as follows: ("HIV" or "AIDS" or "human immunodeficiency virus" or "acquired immunodeficiency syndrome") and ("homosexual" or "gay" or "men who have sex with men" or "MSM" or "bisexual" or "Tongzhi" [the Chinese term referring to homosexual men]) and ("China" or "Chinese") and ("prevalence" or "infection" or "associated risk" or "infection status" or "epidemic status" or "surveillance"). We also searched relevant reference lists and relevant journals manually, which were not mentioned in the introduction, and corresponded with authors to obtain the original data if necessary. We did not include grey literature (i.e., literature that had not been formally published). This systematic analysis adhered to the Preferred Reporting Items for Systematic Reviews and Meta-Analyses (PRISMA) guidelines [10].

\section{Inclusion and exclusion criteria}

Studies with the following criteria were included to assess the prevalence of HIV among MSM: (i) studies involving MSM in mainland China; (ii) studies that required both presumptive and confirmatory tests for the HIV diagnosis; (iii) the English version of a study if the study was reported in both Chinese and English; and (iv) the comprehensive article (i.e., prevalence of HIV and its possible related risk factors) if multiple publications reported results based on the same research. Data from eligible studies were extracted by two reviewers independently.

We excluded duplicate studies within and between databases, studies with no numerical estimates, studies of Chinese populations conducted outside of mainland China, reviews, and viewpoints. We excluded animal studies and studies with a self-reported HIV status unconfirmed by tests. Studies with a sample size less than 30 were excluded [7]. Disagreements were resolved by discussion. If no consensus could be reached, the issue was referred to a third author.

\section{Quality assessment}

The quality assessment tool for systematic reviews of observational studies (QATSO) was selected to evaluate the quality of the included studies, and a validated quality assessment tool was used to assess HIV prevalence/ risk behaviours among MSM [11]. Items were scored as 0,1 , and NA, representing "no," "yes," and "not applicable," respectively. The total score of each eligible study had to be above $33 \%$ (scores of 0 to $33 \%, 33$ to $66 \%$, and 67 to $100 \%$ represented "poor" "satisfactory," and "good" quality studies, respectively.)

\section{Statistical analysis}

We calculated the prevalence estimates with logit transformation, and a systematic analysis was conducted to calculate the pooled estimates following the methods suggested by DerSimonian and Laird [12, 13]. ClopperPearson confidence intervals were calculated for all prevalence estimates. An analysis of heterogeneity was performed using Cochran's Q test $(p<0.10$ indicating significant heterogeneity) and the $I^{2}$ statistic. $I^{2}$ values of 25,50 , and $75 \%$ represented low, moderate, and high degrees of heterogeneity, respectively. If the data were heterogeneous, random-effects models were used for the systematic analysis [14].

Many factors can affect homogeneity between studies. Therefore, we performed subgroup analyses to explore the potential sources of between-study heterogeneity. We calculated the prevalence of HIV among MSM by age, education, marital status, geographical distribution, occupation, gender of first sexual partner, and condom use in the last 6 months. Potential publication bias was assessed for significance using Begg's test and was graphically explored by generating funnel plots. 
All analyses were performed using $\mathrm{R}$ version 3.2.2 [15, $16]$.

\section{Results}

As shown in Fig. 1, a total of 3368 relevant articles were identified, of which 760 were further screened, and 355 cross-sectional studies (51 published in English and 304 in Chinese, which included 571,328 MSM) were finally included in the systematic analysis [10, 11, 14-366]. The characteristics of the included studies are summarized in Table 1.

\section{Characteristics of the selected studies}

The 355 eligible articles included in this study covered 59 cities from 30 provinces and municipalities of China (no studies were from Tibet). The sample size of the selected studies ranged from 30 to 1,498,841 (mean 4373, 95\% confidence interval [CI]: 455 - 8290) [24, 25]. Among the 355 selected articles, 6 reported results for multiple study sites, and 79 reported HIV prevalence estimates for more than one time period, resulting in a total of 581 HIV prevalence estimates. The first included study was reported in 2001 [19], with an HIV prevalence of $1.31 \%$, and the studies provided overall estimates of the HIV prevalence among MSM in China from 2001 to 2018.

The sampling methods varied, with 123 studies using snowball sampling, 39 studies using respondent-driven sampling (RDS), 82 studies sampling from time-venue, 39 studies using multiple recruitment methods, and 11 applying convenience sampling methods. The analysed data indicated that the largest proportion (35.6, 95\% CI: $32.3-39.9 \%$ ) searched for sexual partners on the internet; among the other locations, 25.9\% (95\% CI: 22.4-27.0\%) searched at bars/night clubs/tearooms, 13.2\% (95\% CI: 12.4-14.5\%) searched at public bathhouses/saunas, and 12.4\% (95\% CI: 10.9-14.3\%) searched at parks.

We found a publication bias, the problem that results from systematic differences between the results of all the completed studies on a topic and the results of the subset of those studies that are published, across the studies reporting the HIV prevalence $(t=-4.12, p=0.0011)$ (Fig. 2), which must be taken especially seriously, as it presents perhaps the greatest threat to the validity of this method.

\section{Study quality assessment}

In the quality assessment, 214 of the included studies were considered "good" quality (values between 67 and 100\%), 141 were considered "satisfactory" (values between 33 and 66\%), and none were considered "poor" (values between 0 and 33\%).

\section{Demographic information}

The demographic characteristics are detailed in Table 1. Most participants $(68.7 \%)$ were single, although $22.3 \%$ had married a woman, $2.5 \%$ were cohabiting with their same-sex partner, and 5.0\% were divorced or widowed. The sexual behaviour data indicated that $58.9 \%$ exclusively had sex with men, $33.8 \%$ had sex with both men and women, $2.8 \%$ were heterosexual, and $5.7 \%$ were undetermined.

\section{Prevalence of HIV infections among MSM}

Overall, the national HIV prevalence among MSM from 2001 to 2018 was $5.7 \%$ (95\% CI: $5.4-6.1 \%, N=355$ ), with

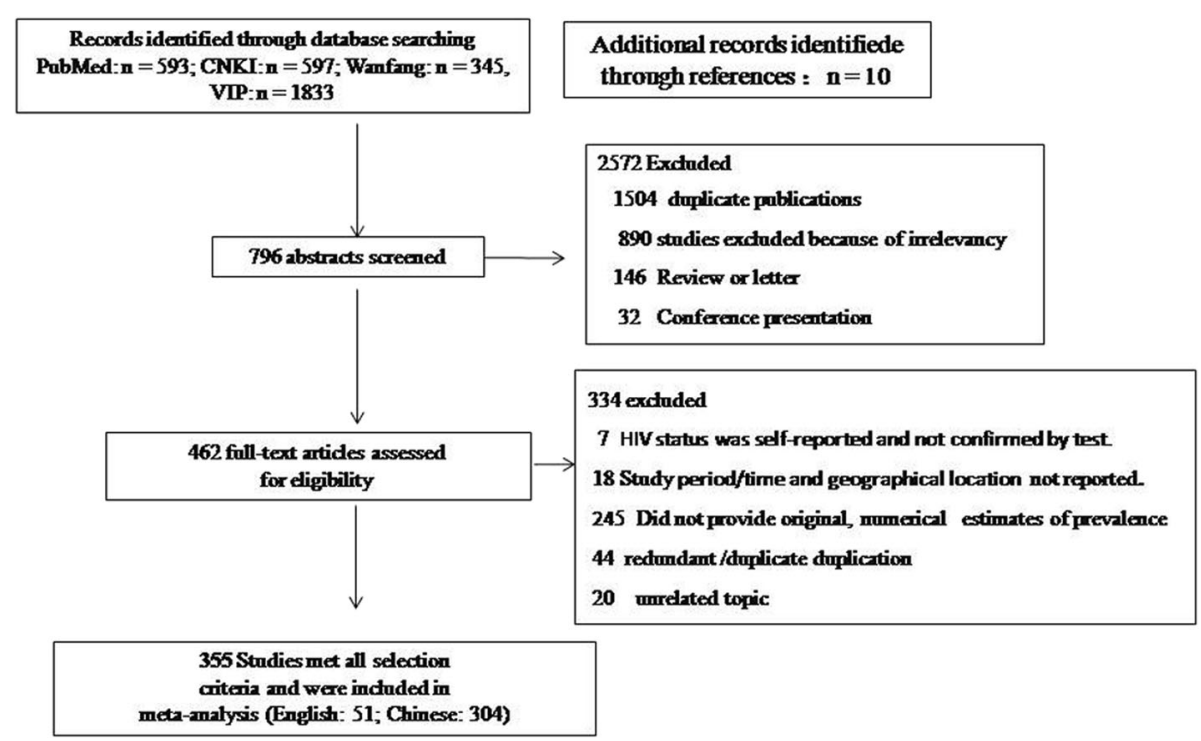

Fig. 1 Flow chart showing the selection process for studies included in the systematic analyses 
Table 1 Characteristics of Study Participants (355 studies)

\begin{tabular}{|c|c|c|c|}
\hline Variable & Number of studies & $\mathrm{n}$ or $\mathrm{n} / \mathrm{N}$ & Percentage \\
\hline \multicolumn{4}{|l|}{ Age (years) } \\
\hline$<20$ & 93 & $8856 / 102,298$ & $4.6 \%[3.8 \% ; 7.3 \%]$ \\
\hline $20-29$ & 86 & $43.354 / 80,249$ & $55.3 \%$ [52.9\%; 57.6\%] \\
\hline $30-39$ & 85 & $19,141 / 73,768$ & $24.7 \%$ [23.5\%; 25.9\%] \\
\hline $40-49$ & 41 & $3643 / 34,063$ & $10.2 \%[9.0 \% ; 11.4 \%]$ \\
\hline $50+$ & 39 & $1584 / 42,046$ & $3.2 \%[2.6 \% ; 4.1 \%]$ \\
\hline \multicolumn{4}{|l|}{ Sample size } \\
\hline$<100$ & 15 & 1130 & $0.2 \%$ \\
\hline $101-200$ & 41 & 6372 & $1.1 \%$ \\
\hline $201-500$ & 138 & 49,243 & $0.8 \%$ \\
\hline $501-1000$ & 63 & 45,714 & $8.0 \%$ \\
\hline $1001-2000$ & 58 & 83,815 & $14.7 \%$ \\
\hline $2001-5000$ & 25 & 76,743 & $13.4 \%$ \\
\hline $5001-10,000$ & 9 & 63,424 & $11.1 \%$ \\
\hline$>10,001$ & 6 & 244,887 & $42.9 \%$ \\
\hline \multicolumn{4}{|l|}{ Marital status } \\
\hline Single & 249 & $183,832 / 267,519$ & $68.7 \%$ [65.3\%; 73.6\%] \\
\hline Cohabitating & 98 & $3508 / 129,646$ & $2.7 \%[2.1 \% ; 3.1 \%]$ \\
\hline Married & 193 & $153,060 / 335,726$ & $22.3 \%$ [19.8\%; 25.0\%] \\
\hline Divorced or widowed & 195 & $11,126 / 224,119$ & $5.0 \%[4.2 \% ; 5.3 \%]$ \\
\hline \multicolumn{4}{|l|}{ Current level of education } \\
\hline Illiterate & 38 & $316 / 34,779$ & $0.8 \%[0.6 \% ; 1.3 \%]$ \\
\hline Primary school & 74 & $1371 / 42,411$ & $3.21 \%[2.7 \% ; 3.8 \%]$ \\
\hline Junior high school & 117 & $17,979 / 95,030$ & $19.1 \%[17.8 \% ; 20.5 \%]$ \\
\hline Senior high school & 212 & $84,723 / 245,166$ & $34.4 \%[33.5 \% ; 35.5 \%]$ \\
\hline College or above & 250 & $180,806 / 418,465$ & $43.2 \%[42.7 \% ; 45.2 \%]$ \\
\hline \multicolumn{4}{|l|}{ Sexual orientation } \\
\hline Homosexual & 143 & $53,653 / 92,721$ & $58.9 \%[57.3 \% ; 60.4 \%]$ \\
\hline Bisexual & 116 & $23,117 / 65,545$ & $33.8 \%[32.1 \% ; 35.6 \%]$ \\
\hline Heterosexual & 85 & $2370 / 47,974$ & $2.8 \%[2.1 \% ; 3.7 \%]$ \\
\hline Undetermined & 71 & $2063 / 38,423$ & $5.7 \%[4.9 \% ; 6.7 \%]$ \\
\hline \multicolumn{4}{|c|}{ Main location to seek homosexual partners } \\
\hline Internet & 101 & $112,979 / 316,944$ & $35.6 \%[32.3 \% ; 39.9 \%]$ \\
\hline Parks & 85 & $17,547 / 141,598$ & $12.4 \%[10.9 \% ; 14.3 \%]$ \\
\hline Public bathhouses/saunas & 98 & $40,029 / 303,129$ & $13.2 \%[12.4 \% ; 14.5 \%]$ \\
\hline Bar/night club/tearoom & 100 & $42,978 / 165,416$ & $25.9 \%[22.4 \% ; 27.0 \%]$ \\
\hline \multicolumn{4}{|l|}{ Sampling methods } \\
\hline Respondent driven sampling (RDS) & 39 & 28,952 & $5.0 \%$ \\
\hline Snowball & 123 & 271,041 & $47.0 \%$ \\
\hline Time-venue & 82 & 95,268 & $16.3 \%$ \\
\hline Convenience & 11 & 6828 & $1.2 \%$ \\
\hline Multiple methods & 39 & 121,732 & $20.2 \%$ \\
\hline Other or not defined & 61 & 58,895 & $10.3 \%$ \\
\hline
\end{tabular}

Condom use (in the last 6 months) 
Table 1 Characteristics of Study Participants (355 studies) (Continued)

\begin{tabular}{|c|c|c|c|}
\hline Variable & Number of studies & $\mathrm{n}$ or $\mathrm{n} / \mathrm{N}$ & Percentage \\
\hline \multicolumn{4}{|l|}{ During sex with men } \\
\hline Always & 163 & $113,092 / 280,617$ & $41.5 \%[40.1 \% ; 42.8 \%]$ \\
\hline Sometimes & 119 & $46,927 / 90,253$ & $48.3 \%[46.7 \% ; 50.0 \%]$ \\
\hline Never & 101 & $7890 / 86,014$ & $10.1 \%[9.0 \% ; 11.4 \%]$ \\
\hline \multicolumn{4}{|l|}{ During commercial sex with men } \\
\hline Always & 63 & $8622 / 19,537$ & $52.1 \%[48.2 \% ; 56.0 \%]$ \\
\hline Sometimes & 33 & $1274 / 3549$ & $33.6 \%$ [29.5\%; 38.0\%] \\
\hline Never & 33 & $294 / 3533$ & $9.0 \%[6.0 \% ; 13.4 \%]$ \\
\hline \multicolumn{4}{|l|}{ When purchasing sex } \\
\hline Always & 9 & $282 / 623$ & $50.4 \%$ [39.3\%; 61.6\%] \\
\hline Sometimes & 5 & 190/487 & $34.0 \%[25.7 \% ; 43.3 \%]$ \\
\hline Never & 5 & $69 / 487$ & $14.3 \%$ [10.1\%; 19.7\%] \\
\hline \multicolumn{4}{|l|}{ During anal sex with men when selling sex } \\
\hline Always & 10 & $538 / 913$ & $60.7 \%[52.2 \% ; 68.7 \%]$ \\
\hline Sometimes & 5 & $234 / 669$ & $31.2 \%$ [22.8\%; 40.9\%] \\
\hline Never & 5 & $62 / 669$ & $10.7 \%$ [6.3\%; 17.5\%] \\
\hline \multicolumn{4}{|l|}{ During sex with a woman } \\
\hline Always & 108 & $16,282 / 61,944$ & $29.6 \%$ [28.1\%; 31.1\%] \\
\hline Sometimes & 68 & $5396 / 16,474$ & $34.3 \%$ [31.4\%; 37.3\%] \\
\hline Never & 68 & $5937 / 17,665$ & $34.2 \%$ [31.2\%; 37.4\%] \\
\hline \multicolumn{4}{|l|}{ Occupation } \\
\hline Student & 81 & $8592 / 56,128$ & $16.3 \%$ [14.3\%; 18.5\%] \\
\hline Teacher & 20 & $150 / 5460$ & $3.0 \%[2.4 \% ; 3.8 \%]$ \\
\hline Office staff & 51 & $8946 / 39,117$ & 13.9\% [11.4\%; 16.7\%] \\
\hline Farmer & 22 & $833 / 19,603$ & $4.2 \%[2.4 \% ; 7.4 \%]$ \\
\hline Service business employee & 63 & $14,358 / 51,468$ & 25.7\% [22.8\%;28.9\%] \\
\hline Jobless or job-seeking & 26 & $1558 / 15,119$ & $9.2 \%[6.7 \% ; 12.5 \%]$ \\
\hline Worker & 46 & $4793 / 36,243$ & 13.0\% [11.3\%; 14.9\%] \\
\hline Retired & 7 & $41 / 2591$ & $1.9 \%[0.8 \% ; 4.3 \%]$ \\
\hline Food and beverage service personnel & 20 & $573 / 8375$ & $6.0 \%[4.3 \% ; 8.5 \%]$ \\
\hline \multicolumn{4}{|l|}{ Sexual debut partner } \\
\hline Male & 54 & $23,608 / 38,680$ & $60.2 \%[57.8 \% ; 62.6 \%]$ \\
\hline Female & 54 & $14,547 / 38,680$ & $38.0 \%[35.5 \% ; 40.5 \%]$ \\
\hline \multicolumn{4}{|l|}{ HIV/AIDS-related knowledge } \\
\hline Awareness rate of HIV/AIDS knowledge & 104 & $225,951 / 254,330$ & $91.1 \%[89.5 \% ; 92.4 \%]$ \\
\hline HIV can be transmitted through the blood or blood products & 70 & $29,812 / 31,420$ & $95.7 \%[94.6 \% ; 96.5 \%]$ \\
\hline HIV can be sexually transmitted & 73 & $28,601 / 30,682$ & $97.6 \%[95.7 \% ; 98.7 \%]$ \\
\hline HIV can spread through mosquito or other insect bites & 62 & $20,718 / 28,888$ & 74.2\% [70.7\%; 77.4\%] \\
\hline People who look healthy can still have HIV & 61 & $20,801 / 27,084$ & $82.2 \%[78.5 \% ; 85.4 \%]$ \\
\hline A pregnant woman with HIV can transmit the virus to her baby & 70 & $26,869 / 29,382$ & $92.8 \%$ [91.0\%; 94.3\%] \\
\hline Sharing needles for drug use with someone who has & 58 & $24,262 / 25,621$ & $95.7 \%[94.5 \% ; 96.6 \%]$ \\
\hline HIV or AIDS could cause HIV infection & 63 & $24,072 / 29,093$ & $87.1 \%$ [84.3\%; 89.4\%] \\
\hline \multicolumn{4}{|l|}{ Drug use } \\
\hline Drug use & 83 & $1044 / 59,764$ & $1.5 \%[1.1 \% ; 2.0 \%]$ \\
\hline
\end{tabular}


Table 1 Characteristics of Study Participants (355 studies) (Continued)

\begin{tabular}{llll}
\hline Variable & Number of studies & $n$ or n/N & Percentage \\
\hline No drug use & 20 & $16,783 / 17,268$ & $97.6 \%[95.7 \% ; 98.7 \%]$ \\
\hline Figures in parentheses are 95\% Cls; $n$, number of MSM in the subgroup; $N$, total number investigated in the subgroup &
\end{tabular}

study prevalence rates ranging from 0\% (95\% CI: 0.1$2.5 \%$ ) to $22.91 \%$ (95\% CI: $18.1-28.3 \%)$ [17, 341]. Substantial heterogeneity existed between the studies ( $p$ for $\mathrm{Q}$ test, $\left.p<0.0001 ; I^{2}=98.0 \%\right)$.

\section{Chronological prevalence of HIV infections among MSM}

Based on the study years selected for our investigation, we estimated chronological prevalence of HIV in China by meta-regression analysis $\left(I^{2}=95.9 \%, P<0.001\right)$, demonstrating an increased tendency as time progressed (Fig. 3).

Relationships between HIV prevalence and age, education, marital status, occupation, ethnicity, and sexual debut partner

Table 2 shows the age-specific prevalence of HIV. For each 10-year increase in age, the prevalence of HIV also increased from $4.6 \%$ in people aged $<20$ years to $7.2 \%$ in people aged 20-29 years to the highest prevalence $(19.3 \%)$ in those aged $>50$ years.

The prevalence of HIV decreased with increasing years of education, with a prevalence in the illiterate group of 16.8\% (95\% CI: 6.4-37.3\%), which was higher than the prevalence rate among those who had received an education. Of the assessed occupations (including teacher, office staff, farmer, service business employee, unemployed and job-seeking, and worker), the prevalence of HIV was highest among farmers at 14.8\% (95\% CI: 3.8-43.2\%).

The prevalence rates of HIV by sexual orientation were $7.0,6.1,7.5$, and $7.6 \%$ for the homosexual, bisexual, heterosexual, and undetermined groups, respectively. Although the internet was a major venue for seeking male sex partners among Chinese MSM (35.6, 95\% CI: 32.3$39.9 \%, N=101)$, MSM seeking male sex partners in bathhouses/saunas had the highest prevalence of HIV (13.4, 95\% CI: 10.3-17.1\%, $N=22$ ).

The odds ratio (OR) of HIV for those whose first sexual encounter was with a male compared to those with a first sexual encounter with a female was 0.6 (95\% CI: 0.5-0.7), suggesting that in China, MSM with a female sexual debut partner had a higher HIV prevalence than those with a male sexual debut partner. Drug use was not a significant contributor to HIV transmission among Chinese MSM (OR: 1.14, 95\% CI: 0.31-4.21).

\section{Geographical characteristics of the HIV prevalence}

To determine the geographical characteristics of the HIV prevalence in China, we analysed the differences in prevalence by geographical divisions in China based on its provinces or municipalities. The number of studies, total HIV-positive population, and pooled sample size

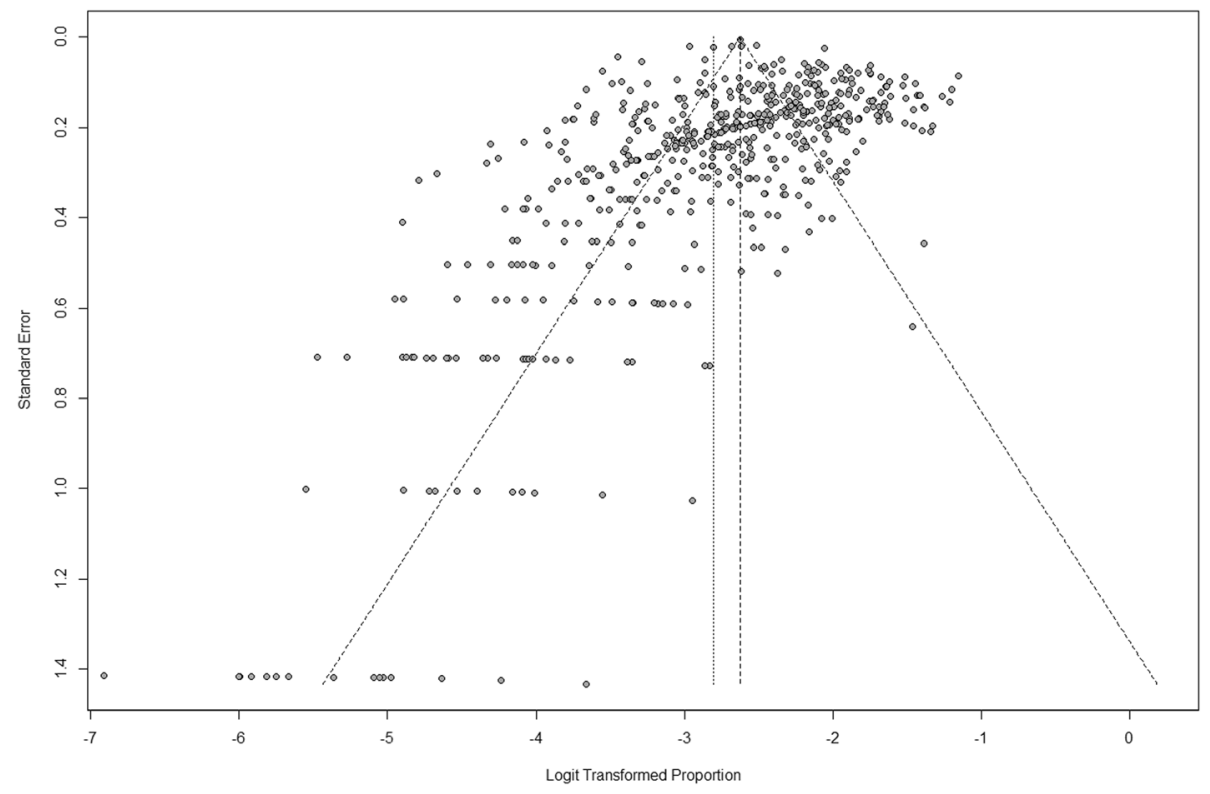

Fig. 2 Funnel plot showing the potential publication bias 


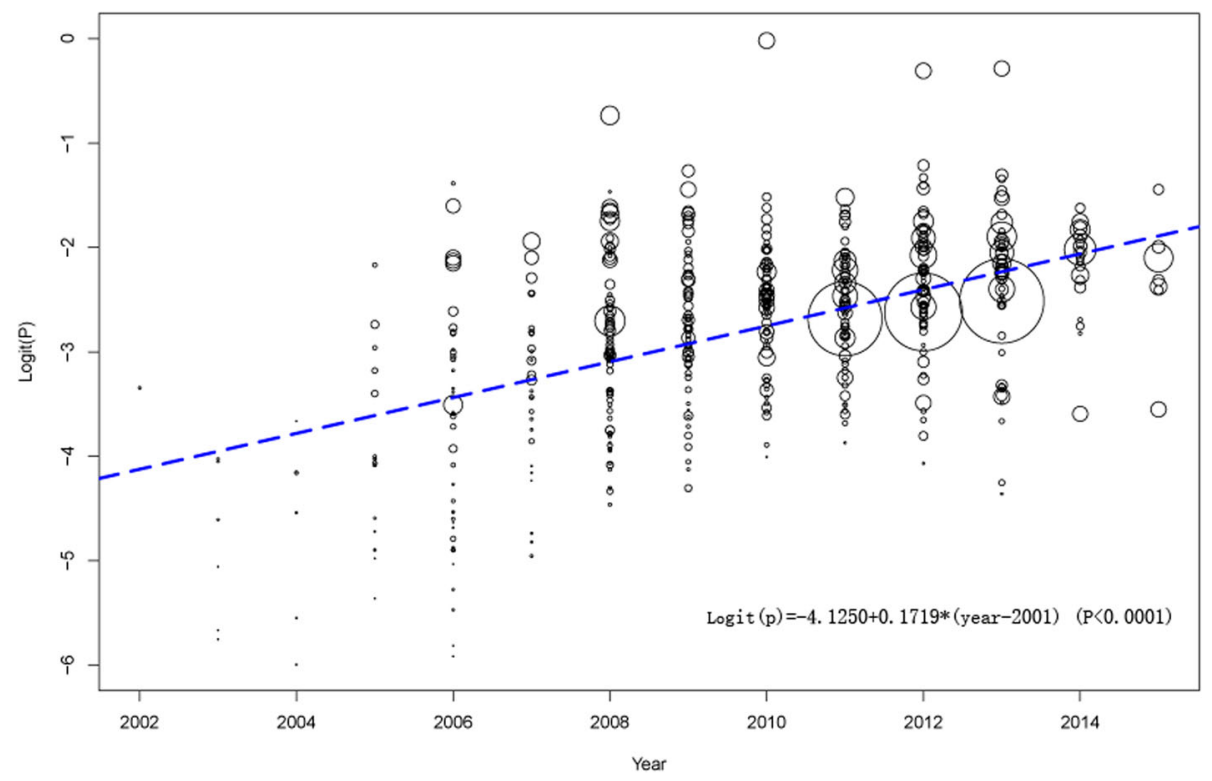

Fig. 3 Chronological prevalence of HIV infection among MSM analysed by meta-regression

were summarized for the different geographical divisions (Fig. 4).

Overall, the highest pooled HIV prevalence among MSM was found in southwest China (10.7, 95\% CI: 9.3$12.2 \%, N=91$ ), in which Chongqing city had the highest HIV prevalence (13.8, 95\% CI: $12.8-14.9 \%, N=24)$, followed by east China (6.3, 95\% CI: 5.6-7.0\%, $N=167$ ), which had a prevalence higher than the national average. The pooled HIV prevalence among MSM in northeast China (4.2, 95\% CI: 3.4-5.0\%, $N=58$ ), north China (5.2, 95\% CI: 4.4-6.1\%, $N=66)$, northwest China (3.7, 95\% CI: 3.0-4.5\%, $N=57$ ), and south China (5.1, 95\% CI: 4.4$5.9 \%, N=121)$ were lower than the prevalence of the country as a whole.

\section{Condom use information (in the last 6 months)}

Participants who had engaged in unprotected sex in the past 6 months had a higher risk of HIV infection than those who reported protected sex (either sometimes or always using a condom). The ORs for participants who never used a condom during sex with men, during commercial sex with men, and during sex with a woman in the past 6 months were 0.11 (95\% CI: 0.08-0.14), 0.11 (95\% CI: 0.09-0.13), and 0.07 (95\% CI: 0.03-0.14), respectively.

\section{Discussion}

\section{Study findings}

To the best of our knowledge, this study is the first large-scale systematic analysis of the epidemiology of HIV infection among MSM in China up to 2018. The study included 355 eligible studies that covered 59 cities from 30 provinces and municipalities. All the studies were of "satisfactory" or "good" quality, and the results of these studies were heterogeneous. Significant publication bias (Begg's test, $t=-4.12$, $p$-value $=0.0011$ ) existed across the studies reporting the prevalence of HIV. The national estimate of HIV prevalence among MSM from 2001 to 2018 was $5.7 \%$ (95\% CI: 5.4-6.1\%), with study prevalence rates ranging from $0 \%$ (95\% CI: $0.1-2.5 \%)$ to $22.9 \%$ (95\% CI: 18.1-28.3\%) [17, 338]. The prevalence of HIV among MSM increased substantially between 2001 and 2018. These findings might have important policy implications because the prevalence also differed by age, education, occupation, and condom use. The data from this study indicated that the HIV prevalence differed by region, and a high burden of HIV infection was observed among MSM in southwest China, especially in Chongqing city. Although the internet was a major venue used by Chinese MSM to search for male sex partners, MSM who sought partners at bathhouses, saunas, and massage rooms had the highest HIV prevalence. Studies using snowball sampling had a higher prevalence of HIV infection than studies using RDS, convenience sampling, or multiple sampling methods. A possible explanation for this finding is that individuals with high-risk behaviours are more likely to accept HIV testing through snowballing sampling [2].

The present study provides insights into the national HIV prevalence among MSM over the past 18 years and proposes a suggestion for China's health department to implement more effective prevention strategies and policies in the future. The national estimate of HIV prevalence in China differed somewhat from those of other 
Table 2 Stratified analyses of HIV prevalence among MSM in China

\begin{tabular}{|c|c|c|c|c|c|c|}
\hline \multirow[t]{2}{*}{ Variable } & \multirow{2}{*}{$\begin{array}{l}\text { Number } \\
\text { of } \\
\text { studies }\end{array}$} & \multirow[t]{2}{*}{ HIV prevalence } & \multicolumn{4}{|c|}{ Heterogeneity of included studies } \\
\hline & & & $l^{2}$ & Q & $p$ & OR \\
\hline \multicolumn{7}{|l|}{ Age (yrs.) } \\
\hline$<20$ & 33 & $4.6 \%[3.4 \% ; 6.3 \%]$ & $64.0 \%$ & 79.4 & $<0.0001$ & \\
\hline $20-29$ & 32 & $7.2 \%[5.9 \% ; 8.7 \%]$ & $91.6 \%$ & 276.2 & $<0.0001$ & \\
\hline $30-39$ & 30 & $11.8 \%[10.0 \% ; 13.8 \%]$ & $75.2 \%$ & 120.8 & $<0.0001$ & \\
\hline $40-49$ & 30 & $13.8 \%[11.0 \% ; 17.1 \%]$ & $51.8 \%$ & 37.4 & 0.0047 & \\
\hline $50+$ & 13 & $19.3 \%[13.1 \% ; 27.4 \%]$ & $50.2 \%$ & 26.1 & 0.0166 & \\
\hline \multicolumn{7}{|l|}{ Sampling methods } \\
\hline RDS & 39 & $5.4 \%[4.7 \% ; 6.3 \%]$ & $90.3 \%$ & 627.4 & $<0.0001$ & \\
\hline Snowball & 126 & $6.4 \%[5.9 \% ; 7.0 \%]$ & $96.6 \%$ & 3132.0 & $<0.0001$ & \\
\hline Time-venue & 83 & $5.4 \%[4.6 \% ; 6.3 \%]$ & $96.9 \%$ & 2694.4 & $<0.0001$ & \\
\hline Convenience & 11 & $4.2 \%[3.3 \% ; 7.3 \%]$ & $96.2 \%$ & 173.5 & $<0.0001$ & \\
\hline Multiple methods & 42 & $5.0 \%[3.9 \% ; 6.4 \%]$ & $99.0 \%$ & 3762.7 & $<0.0001$ & \\
\hline \multicolumn{7}{|l|}{ Marital status } \\
\hline Single & 57 & $6.4 \%[5.5 \% ; 7.5 \%]$ & $94.5 \%$ & 876.3 & $<0.0001$ & \\
\hline Cohabitating & 21 & $11.5 \%$ [7.8\%; 16.5\%] & $67.8 \%$ & 65.3 & $<0.0001$ & \\
\hline Married & 42 & $10.6 \%$ [9.2\%; 12.0\%] & $72.5 \%$ & 152.9 & $<0.0001$ & \\
\hline Divorced or widowed & 49 & $12.8 \%[10.0 \% ; 16.4 \%]$ & $81.6 \%$ & 240.9 & $<0.0001$ & \\
\hline \multicolumn{7}{|l|}{ Current level of education } \\
\hline Illiterate & 3 & $16.8 \%$ [6.4\%;37.3\%] & $0.0 \%$ & 0.8 & 0.6683 & \\
\hline Primary school & 11 & $15.6 \%$ [11.0\%;21.6\%] & $25.4 \%$ & 14.7 & 0.1948 & \\
\hline Junior high school & 20 & $9.8 \%[7.4 \% ; 12.9 \%]$ & $86.8 \%$ & 151.8 & $<0.0001$ & \\
\hline Senior high school & 50 & $7.6 \%$ [6.4\%; 9.0\%] & $89.5 \%$ & 428.6 & $<0.0001$ & \\
\hline College or above & 62 & $5.7 \%$ [5.0\%; 6.5\%]] & $87.7 \%$ & 464.9 & $<0.0001$ & \\
\hline \multicolumn{7}{|l|}{ Sexual orientation } \\
\hline Homosexual & 23 & $7.0 \%[5.4 \% ; 9.1 \%]$ & $93.4 \%$ & 540.3 & $<0.0001$ & \\
\hline Bisexual & 10 & $6.1 \%[4.5 \% ; 8.3 \%]$ & $69.0 \%$ & 32.2 & 0.0004 & \\
\hline Heterosexual & 11 & $7.5 \%$ [4.4\%; 12.7\%] & $59.3 \%$ & 27.0 & 0.0045 & \\
\hline Undetermined & 7 & $7.6 \%[3.2 \% ; 16.8 \%]$ & $0.0 \%$ & 15.4 & 0.0175 & \\
\hline \multicolumn{7}{|c|}{ Main location to seek homosexual partners } \\
\hline Internet & 20 & $7.3 \%[5.8 \% ; 9.1 \%]$ & $94.2 \%$ & 314.7 & $<0.0001$ & \\
\hline Parks & 19 & $6.0 \%[4.8 \% ; 7.4 \%]$ & $38.2 \%$ & 38.2 & 0.0037 & \\
\hline Public bathhouses/saunas & 22 & $13.4 \%[10.3 \% ; 17.1 \%]$ & $88.6 \%$ & 162.3 & $<0.0001$ & \\
\hline Bar/night/club/tearoom & 23 & $7.4 \%[5.8 \% ; 9.3 \%]$ & $98.9 \%$ & 141.2 & $<0.0001$ & \\
\hline \multicolumn{7}{|l|}{ Ethnicity } \\
\hline Han Chinese & 15 & $6.3 \%[4.9 \% ; 8.0 \%]$ & $95.6 \%$ & 317.7 & $<0.0001$ & $0.78[0.30,2.03]$ \\
\hline Other & 15 & $7.0 \%[3.4 \% ; 14.0 \%]$ & $93.6 \%$ & 218.9 & $<0.0001$ & \\
\hline \multicolumn{7}{|c|}{ Condom use (in the last 6 months) } \\
\hline \multicolumn{7}{|l|}{ During sex with men } \\
\hline Always & 27 & $4.4 \%[3.3 \% ; 5.8 \%]$ & $91.1 \%$ & 321.5 & $<0.0001$ & \\
\hline Sometimes & 27 & $8.2 \%[6.3 \% ; 10.5 \%]$ & $96.0 \%$ & 510.5 & $<0.0001$ & \\
\hline Never & 27 & $9.9 \%[7.4 \% ; 13.1 \%]$ & $84.5 \%$ & 145.1 & $<0.0001$ & \\
\hline \multicolumn{7}{|c|}{ During commercial sex with men } \\
\hline Always & 15 & $2.9 \%$ [1.6\%; 5.0\%] & $69.8 \%$ & 39.8 & $<0.0001$ & \\
\hline
\end{tabular}


Table 2 Stratified analyses of HIV prevalence among MSM in China (Continued)

\begin{tabular}{|c|c|c|c|c|c|c|}
\hline \multirow[t]{2}{*}{ Variable } & \multirow{2}{*}{$\begin{array}{l}\text { Number } \\
\text { of } \\
\text { studies }\end{array}$} & \multirow[t]{2}{*}{ HIV prevalence } & \multicolumn{4}{|c|}{ Heterogeneity of included studies } \\
\hline & & & $P^{2}$ & $\mathrm{Q}$ & $p$ & OR \\
\hline Sometimes & 15 & $6.6 \%[4.0 \% ; 10.7 \%]$ & $85.2 \%$ & 59.8 & $<0.0001$ & \\
\hline Never & 14 & $8.5 \%[5.3 \% ; 13.2 \%]$ & $26.3 \%$ & 23.7 & 0.0345 & \\
\hline \multicolumn{7}{|c|}{ Condom use during sex with a woman in the past 6 months } \\
\hline Always & 11 & $4.1 \%[2.5 \% ; 6.4 \%]$ & $48.1 \%$ & 20.5 & 0.021 & \\
\hline Sometimes & 9 & $3.4 \%[1.7 \% ; 6.6 \%]$ & $80.2 \%$ & 42.4 & $<0.0001$ & \\
\hline Never & 10 & $5.9 \%[3.2 \% ; 10.7 \%]$ & $86.9 \%$ & 71.4 & $<0.0001$ & \\
\hline \multicolumn{7}{|l|}{ Occupation } \\
\hline Student & 12 & $6.1 \%[4.5 \% ; 8.4 \%]$ & $59.8 \%$ & 29.8 & 0.0029 & \\
\hline Teacher & 2 & $5.3 \%[1.1 \% ; 22.8 \%]$ & $0.0 \%$ & 0.6 & 0.7348 & \\
\hline Office staff & 12 & $8.0 \%$ [6.2\%; 10.2\%] & $76.2 \%$ & 50.5 & $<0.0001$ & \\
\hline Farmer & 2 & $14.8 \%[3.8 \% ; 43.2 \%]$ & $93.4 \%$ & 30.3 & $<0.0001$ & \\
\hline Service business employee & 8 & $8.1 \%[5.6 \% ; 11.6 \%]$ & $90.3 \%$ & 82.7 & $<0.0001$ & \\
\hline Jobless or job-seeking & 9 & $10.3 \%$ [8.4\%; 12.6\%] & $31.2 \%$ & 13.1 & 0.159 & \\
\hline Worker & 8 & $8.6 \%[7.5 \% ; 9.9 \%]$ & $33.1 \%$ & 12.0 & 0.1533 & \\
\hline \multicolumn{7}{|l|}{ Sexual debut partner } \\
\hline Male & 8 & $6.8 \%$ [4.0\%; 10.1\%] & $95.4 \%$ & 152.8 & $<0.0001$ & $0.60[0.53,0.69]$ \\
\hline Female & 8 & $10.2 \%[6.6 \% ; 14.4 \%]$ & $94.5 \%$ & 127.4 & $<0.0001$ & \\
\hline \multicolumn{7}{|l|}{ Drug use } \\
\hline Yes & 7 & $6.4 \%[4.2 \% ; 10.0 \%]$ & $42.9 \%$ & 10.5 & 0.1046 & $1.14[0.31,4.21]$ \\
\hline No & 7 & $8.2 \%$ [2.4\%; 17.0\%] & $99.2 \%$ & 770.7 & $<0.0001$ & \\
\hline \multicolumn{7}{|l|}{ Quality ssessment } \\
\hline satisfactory & 142 & $5.5 \%[4.6 \% ; 6.6 \%]$ & $96.5 \%$ & 2481.5 & $<0.0001$ & $0.74[0.60,0.92]$ \\
\hline good & 213 & $7.4 \%$ [6.5\%;8.4\%] & $97.7 \% \%$ & 1823.0 & $<0.0001$ & \\
\hline
\end{tabular}

Figures in parentheses are $95 \% \mathrm{Cls}$; OR, odds ratio

countries or regions. For example, the prevalence of HIV among MSM is estimated to be $19 \%$ in the United States [367], $14.2 \%$ in Brazil, 3.0\% (95\% CI: 2.4-3.6) in the Middle East and North African region, 6.56\% (95\% CI: 5.54-7.57) in eastern Europe and central Asia, 14.74\% (95\% CI: 14.05-15.42) in south and southeast Asia, and $25.4 \%$ in the Caribbean [368]. Our study showed an increased tendency in the HIV prevalence as time progressed $(P<0.001)$ (Fig. 2). The increasing HIV prevalence may be associated with several factors: 1 ) the increasing migration for better employment opportunities and living conditions from regions with a high HIV prevalence, such as from southern China or from the countryside, to large cities, which have a relatively open culture and convenient sexual venues (e.g., bars, saunas, parks, and sex clubs.) [203]; 2) the gradual changes in attitudes towards sex and increased openness of male homosexuality in China with changes in Chinese society, although homosexuality is still not widely accepted by the general population [369]; and 3) the common occurrence of marriage between MSM and women because MSM might act as a bridge for HIV transmission from other MSM to the general population [9]. Additionally, to some extent, the increased HIV prevalence may be due to an increase in the testing rates because HIV testing among Chinese MSM has increased over the past decade.

\section{HIV prevalence in terms of age}

A better understanding of the mechanisms underlying the age-related risks of HIV infection can help address the situation in practice. The findings presented in this article confirmed the notable increase in the HIV prevalence with increasing age in China because HIV was most prevalent in those aged 50 years and older; these results demonstrated a prominent age-dependent increase in HIV. The distribution of HIV cases by age differed somewhat from that of other countries [370]. A higher HIV prevalence was found among MSM aged 15-19 and 20-24 years in the United States and among 15- to 24-year-old MSM in the United Kingdom [369, 371]. The reason for the increasing HIV prevalence in older MSM may be that older MSM have longer durations of exposure to HIV; additionally, unprotected anal 


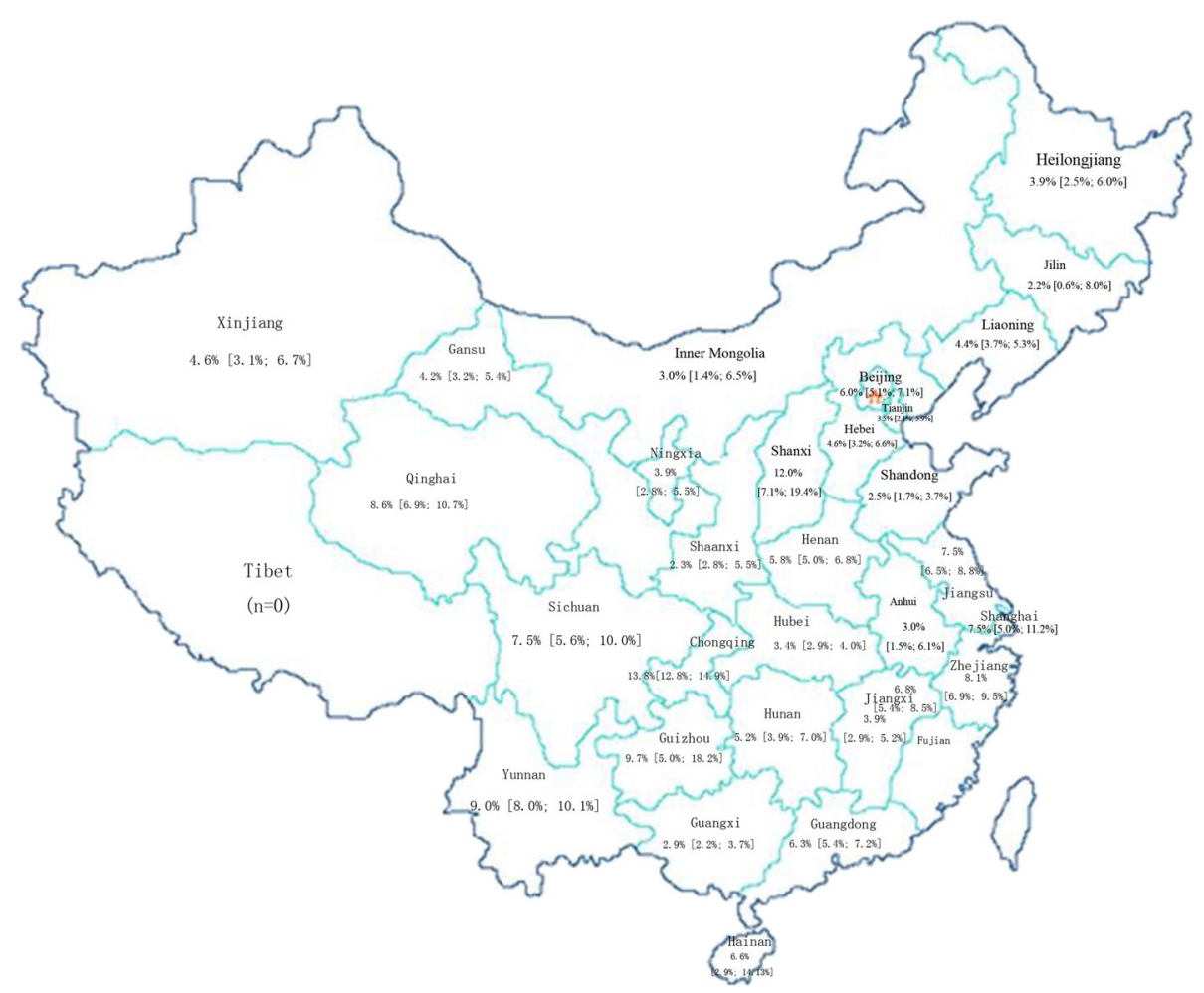

Fig. 4 Map of the geographical characteristics of the HIV prevalence across China

intercourse (UAI) is more common among older MSM than in their younger counterparts, who may also have received a higher level of education [372]. Therefore, behavioural scientists and practitioners alike must address the implications of these findings when developing targeted prevention interventions and treatment services for older MSM [373].

Importantly, the largest subgroup of MSM in this study was those aged $20-29$ years (55.3\% of the MSM, 95\% CI: 52.9-57.6\%), which is similar to findings in the literatures $[1,112,370]$. Although younger MSM may be over sampled, the phenomenon should be taken seriously because younger MSM are sexually active, less able than older MSM to negotiate safer sex with their partners and more likely to have multiple sex partners and engage in more complicated sexual networks. Therefore, China may face a widespread HIV epidemic among young MSM if future timely interventions targeting this population are not implemented.

\section{Relationship between HIV prevalence and geographic location, education, sought sexual partners and occupation}

The HIV prevalence among MSM varied according to geographic location. For example, there was an extraordinarily high HIV prevalence of MSM in the southwest compared to the other regions of China (southwest
China: 10.7\%; northwest China: 3.7\%; central China: 5.1\%; northeast China: $4.2 \%$; north China: $4.7 \%$; and east China: 6.3\%). The high HIV prevalence among MSM in the southwest may be due to several factors: 1) the difference in socioeconomic development between the southwest and other regions of China because the southwest region has a lower economic status and its residents have a lower education level [95]; 2) southwest China includes several areas with a high HIV prevalence, such as Chongqing, which is a city that is accepting towards homosexuality and has very open attitudes about sex [226]; and 3) the increased illicit drug use among MSM in southwest China because drug use is a major risk for HIV transmission among MSM and can contribute to the HIV epidemic [50]. Therefore, to better curb the spread of HIV, targeted measures should be adopted that consider the risk profile of MSM in areas of China with a high HIV prevalence.

Our study found that those who had less education, sought sexual partners at bathhouses or saunas, were farmers and were divorced or widowed were more likely to be infected with HIV. Regarding economic considerations, MSM with less education experience a lack of appropriate health messages and support and are more inclined to seek partners at bathhouses, saunas, or massage rooms due to their low costs [260]. The prevalence of HIV among farmers was $14.8 \%$, which was the highest 
of all occupations examined. One possible explanation for this high prevalence is that farmers have a lower chance of receiving an education than other occupations in China. Yang et al. found that condom use was clearly higher among MSM with a higher level of education, such as college students or teachers, than that among others and that these more educated groups could volunteer to promote HIV intervention efforts and facilitate a reduction in the HIV infection rate among MSM [374].

\section{HIV prevalence and sexual risk behaviours}

Our study indicated that $22.3 \%$ of MSM were married to women; these MSM may conceal their sexual orientation due to the traditional values and social stigma present in China, making it unlikely that they can be reached by traditional prevention measures targeting the general MSM population. Although the proportion of divorced or widowed MSM was only 4.6\%, the HIV prevalence appeared to be higher $(12.8 \%)$ in this population than in the single, married, and cohabitating groups. This higher prevalence may be because MSM who are divorced or widowed no longer have access to a legitimate, routine sexual life and are thus more prone to illegal sexual behaviour and have greater exposure to high-risk environments [327].

Interestingly, HIV knowledge was high in the MSM population (91.1, 95\% CI: 89.5-92.4\%), but consistent condom use was low, reflecting the complexity of the hypothesis that knowledge transfer and behavioural change are keys to HIV prevention. The study revealed that the rate of consistent condom use was lower when MSM had sex with women (29.6\%) than when they had sex with men $(41.5 \%$ for sex with men and $52.1 \%$ for commercial sex with men) over the past 6 months (Table 1). Therefore, MSM are vulnerable to HIV infection from both genders and can serve as a bridge for HIV transmission from one gender to the other. Han et al. reported that MSM who had sex with women were more likely to be married and that once they were HIV carriers, they were likely to exhibit commercial sexual behaviour [119]. This study confirmed that in addition to distribution of accurate and up-to-date information on risky behaviours and effective community-based prevention programmes that make condoms available and accessible, concrete strategies that illustrate and highlight the harm and dangers of not using a condom during penetrative sex need to be implemented to enhance individuals' motivations to change their behavioural patterns and skills and reduce their HIV risk [375].

Our data indicated that drug use was not a significant contributor to HIV transmission among Chinese MSM (OR: 1.14, 95\% CI: 0.31-4.21), suggesting that drug use did not significantly contribute to overall HIV transmission among MSM. However, the increased illicit drug use among Chinese MSM may perpetuate the HIV epidemic, and this relationship may be similar to those in Western countries where drug use is a major risk for HIV transmission [376].

\section{Limitations}

This systematic analysis had several limitations. First, the scarcity of existing research did not allow for subgroup analyses of HIV prevalence by number of sexual partners or for analyses of the differences in condom use among MSM when purchasing or selling sex. Second, this study represented a wide spectrum of MSM in China; the included studies used snowball sampling, RDS, time venue sampling, convenience sampling, and multiple sampling methods. However, few studies in Jilin province $(n=2)$ and Tibet $(n=0)$ were included, which might have affected the regional HIV prevalence among MSM. Finally, significant publication bias $(p$-value $=$ 0.0011) was observed in our analysis. Differences between sampling methods, sample sizes, study locations, and the quality of studies may explain publication heterogeneity. Therefore, readers should be aware that they may be viewing a biased sample of experimental results and should moderate the strength of the conclusions accordingly [377]. Despite the limitations described above, this study employed strict inclusion criteria and applied a valid search strategy to provide an objective, authentic, and current estimate of HIV in China based on a large sample size.

\section{Conclusions}

HIV among MSM is a significant public health challenge in China. Our results showed an increased tendency as time progressed from 2001 to 2018, a higher prevalence of HIV among older MSM than young MSM, and a decreased prevalence with increasing education. These findings illustrate the need for HIV prevention, surveillance, treatment, and intervention strategies among atrisk populations, including evidence-based policy decisions to expand available programmes.

\section{Abbreviations \\ AIDS: Acquired immunodeficiency syndrome; Cl: Confidence interval; CNKI: Chinese National Knowledge Infrastructure; HIV: Human Immunodeficiency Virus; MSM: Men who have sex with men}

\section{Acknowledgements}

Not Applicable.

\section{Authors' contributions}

MJD designed and drafted work. ZFL, HL, QNY, XLL, and BZ was responsible for data collection/analysis. BP contributed to the statistical analysis. QNY and $J J C$ performed data interpretation. All authors read and approved the final manuscript. 


\section{Funding}

This article was funded by the National Natural Science Foundation of China (No. 81471704). The funders had no role in the study design or preparation of this manuscript.

\section{Availability of data and materials}

The datasets used and/or analysed during the current study are available from the corresponding author on reasonable request.

\section{Ethics approval and consent to participate}

No ethics approval was required for this study as it is a systematic analysis using pre-existing, publicly published data.

\section{Consent for publication}

Not applicable.

\section{Competing interests}

The authors declare that they have no competing interests.

\section{Author details}

'The Department of Nuclear Medicine, The First Affiliated Hospital, College of Medicine, Zhejiang University, Zhejiang 310003, People's Republic of China. ${ }^{2}$ Department of Medical Statistics, Chongqing Medical University, Chongqing 400016, People's Republic of China. Infectious Disease Department, College of Medicine, Zhejiang University, Zhejiang 310003, People's Republic of China.

Received: 1 April 2019 Accepted: 11 October 2019

\section{Published online: 27 November 2019}

\section{References}

1. Marcus U, Voss L, Kollan C, Hamouda O. HIV incidence increasing in MSM in Germany: factors influencing infection dynamics. Euro Surveill. 2006;11:15760.

2. Gao L, Zhang L, Jin Q. Meta-analysis: prevalence of HIV infection and syphilis among MSM in China. Sex Transm Infect. 2009;85:354-8.

3. Chinese Ministry of Health. Reports on the epidemic of AIDS in 2011. (Chinese Ministry of Health: Beijing, China), 2011.

4. Zeng X, Zhong X, Peng B, Zhang Y, Kong C, Liu X, Huang A. Prevalence and associated risk characteristics of HIV infection based on anal sexual role among men who have sex with men: a multi-city cross-sectional study in Western China. Int J Infect Dis. 2016:49:111-8.

5. Chinese Ministry of Health. Background of China's HIV/AIDS prevention in 2013. (Chinese Ministry of Health: Beijing, China), 2014.

6. Chow EP, Wilson DP, Zhang J, Jing J, Zhang L. Human immunodeficiency virus prevalence is increasing among men who have sex with men in China: findings from a review and meta-analysis. Sex Transm Dis. 2011;38: 845-57.

7. Meng X, Zou H, Beck J, Xu Y, Zhang X, Miao X, Xu F. Trends in HIV prevalence among men who have sex with men in China 2003-09: a systematic review and meta-analysis. Sex Health. 2013;10:211-9.

8. Li HM, Peng RR, Li J, Yin YP, Wang B, Cohen MS, Chen XS. HIV incidence among men who have sex with men in China: a meta-analysis of published studies. PLoS One. 2011;6:e23431.

9. Zhou Y, Li D, Lu D, Ruan Y, Qi X, Gao G. Prevalence of HIV and syphilis infection among men who have sex with men in China: a meta-analysis. Biomed Res Int. 2014;2014:620431.

10. Zhang L, Wang SB, Yang YW. Analysis of HIV and syphilis infection status and behavioral characteristics in men who have sex with men in Harbin. Chin J AIDS STD. 2018;24:1161-2.

11. Yun CY, Wu JC, Zhou CX. HIV infection status of 321 MSM cases in Haikou City. China Trop Med. 2016;16:739-40.

12. DerSimonian R, Laird N. Meta-analysis in clinical trials. Control Clin Trial. 1986;7:177-88

13. Singh S, Manickam P, Amin AV, Samala N, Schouten LJ, lyer PG, Desai TK. Incidence of esophageal adenocarcinoma in Barrett's esophagus with lowgrade dysplasia: a systematic review and meta-analysis. Gastrointest Endosc. 2014;79:897-909.e4 quiz 983.e1, 983.e3.

14. Chen LP, Chen YH, Huan XP, et al. Prevalence of HIV and syphilis infection and their associated factors among men who have sex with men in Jiangsu Province. Chin J Dis Control Prev. 2017;21:1227-31.
15. Yang Q, Luo YL, Fu J, Liao QH. Analysison AIDS surveillance among men who have sex with men in Jiangxi province during 2011-2015. Chin J AIDS STD. 2016;22:725-7.

16. Wang Y, Zhou WM, Fan J. HIV/AIDS sentinel surveillance and factors influencing HIV infection among men who have sex with men in Mianyang, 2017 South China. J Prev Med. 2018;44:101-5.

17. Jiang J, Cao N, Zhang J, Xia Q, Gong X, Xue H, Yang H, Zhang G, Shao C. High prevalence of sexually transmitted diseases among men who have sex with men in Jiangsu Province, China. Sex Transm Dis. 2006;33:118-23.

18. Jiang SM, Li JZ, Li RY, Zhang HJ, Xiao HC. Investigation on unprotected sex and AIDS knowledge among men who have sex with men in Weihai city. Prev Med Trib. 2006;12:763-4.

19. Xu J, Wu ZJ, Zhang HB, Zhu J, Wu H, Zhu W. Study on the status of HIV infection and syphilis infection among MSM in Hefei and its correlation with the social and sexual partner characteristics of MSM. Mod Prev Med. 2007:34:3009-11 3014

20. Xu J, Zhang HB, Zheng YJ, Wang J, Zhu YB, Li ZR, Hu ZW. The prevalence of syphilis and HIV infection among young men who have sex with men in Hefei city. Chin J Behav Med Sci. 2007;16:205-7.

21. Zhu JL, Zhang HB, Wu HH. High risk sexual behavior and HIV/STD infection rate among 122 MSM from students. Chin J AIDS STD. 2007;13:350-2.

22. Liao MZ, Liu XZ, Fu JH, Qian YS, Zhang XF. Analysis of data of behavioral surveillance in men who have sex with men (MSM) in Shandong Province. Chin J AIDS STD. 2006;12:530-2.

23. Choi KH, Ning Z, Gregorich SE, Pan QC. The influence of social and sexual networks in the spread of HIV and syphilis among men who have sex with men in Shanghai, China. J Acquir Immune Defic Syndr. 2007;45:77-84.

24. Cai X. The analysis of risk behaviors of MSM in Liaocheng and the serological detection for anti-HIV, anti-TP, and anti-HCV antibodies in 2006 Prev med Trib. 2007;13:888-90.

25. Zhu YW, Ruan SM, Yang H, Wang MH, Zhang CQ, Jia Z, Shi ZL, Zhang MY. Investigation on AIDS related knowledge risk behavior and HIV infection in MSM in Ji'nan city. Prev Med Trib. 2007;13:490-49.

26. Guo H, Wei JF, Yang H, Huan X, Tsui SK, Zhang C. Rapidly increasing prevalence of HIV and syphilis and HIV-1 subtype characterization among men who have sex with men in Jiangsu, China. Sex Transm Dis. 2009;36:120-5.

27. Zhang B, Li X, Chu Q, Wang N, Wang Z, Zhou S, Tong C, Zhang J, Guan W, Cui Z. A survey of HIV/AIDS related behaviors among 2250 MSM in nine major cities of China. Chin J AIDS STD. 2008;14:541-7.

28. Wu J, Chen L, Fan HL, Ruan Y. A survey on the prevalence of HIV-1 and syphilis infection and characteristics of sexual behaviors in MSM (men who have sex with men) living in Shanghai. J Diagn Concepts Pract. 2008;7:296-9.

29. Cai GF, Ma QQ, Pan XH, Fu LJ, Xu WX, Shan XR, Yang Q. HIV/AIDS related knowledge, attitude, practice and HIV/STD infection among MSM in two cities of Zhejiang Province. Chin Prevent Med. 2008;9:482-5.

30. Fu LJ, Fang YR, Guo TY. Investigation of the sexual behaviors among the MSM in Shaoxing City of Zhejiang Province. Dis Surveill. 2007;22:818-9.

31. Sun ZX, Lin SF, Wen MQ, Jin AH, Chen JD, Zhu HS. Investigation on STD and AIDS prevalence for men who have sex with men. Mod Prev Med. 2007:34:4130-2.

32. Hu J, Wu L, Zhang Z, Fan W. Investigation of STD/AIDS infection,related knowledge and high-risk sexual behavior among MSM in Huaian city. J Public Health Prev Med. 2008;19:44-5.

33. Han XY, Liu LZ, Zhang W, Ma DL, Zhu FL, Pan J. Investigation on the related nosogenic infection among 635 men who have sex with men in Ji'nan. Prev Med Trib. 2007;13:1091-2.

34. Ruan S, Yang H, Zhu Y, Wang M, Ma Y, Zhao J, McFarland W, Raymond HF. Rising HIV prevalence among married and unmarried among men who have sex with men: Jinan, China. AIDS Behav. 2009:13:671-6.

35. Lu ZX, Ge N, Gao HR, Yan LL, Yu WX. Investigation on AIDS related knowledge, behavior and infection among men who have sex with men (MSM) in Yancheng City from 2007 to 2008. Prev Med Trib. 2009;15:702-3.

36. Feng JF, Lin HJ, Zhang YF, Qiu DH, Wu QH, Shen WW. Investigation on the related knowledge, behavior and infection of HIV/syphilis among men who have sex with men in Taizhou city. Shanghai J Prev Med. 2008;20:531-3.

37. Yang $H_{\text {, Hao }}$, Huan X, Yan H, Guan W, Xu X, Zhang M, Tang W, Wang N, Lau JT. HIV incidence and associated factors in a cohort of men who have sex with men in Nanjing, China. Sex Transm Dis. 2010;37:208-13.

38. Qu SQ, Zhang DP, Wu YH, Zhu H, Zheng XW. Seroprevalence of HIV and risk behaviors among men who have sex with men in a northeast city of China. Chin J STD AIDS Prev Cont. 2002;8:145-7 161. 
39. Wang J, Dong W, Li R, Zhao Z, Xiong B, Gang J. A survey of HIV/STD infection and behaviors among MSM. Chin J Public Health. 2004;20:1377-8.

40. Gu Y, Qu P, Xu L. Survey of knowledge, attitude, behavior and practice related to STI/HIV among male homosexuality in Shenyang. Chin J Public Health. 2004;20:573-4.

41. Li R, Tong W, Zhao ZJ, Jiang XH, Zhang XH. Analysis on the surveillance results and epidemiological characteristics of HIV/AIDS in Dalian. Dis Surveill. 2009;24:852-5

42. Wang J, Luo C, Wen Y. A survey of HIV infection and related behavior among MSM in Harbin City. Chin J AIDS STD. 2008;14:75.

43. Xiao Y, Sun J, Li C, Lu F, Allen KL, Vermund SH, Jia Y. Prevalence and correlates of HIV and syphilis infections among men who have sex with men in seven provinces in China with historically low HIV prevalence. J Acquir Immune Defic Syndr. 2010;53(Suppl 1):S66-73.

44. Xu JJ, Zhang M, Brown K, Reilly K, Wang H, Hu Q, Ding H, Chu Z, Bice T, Shang $\mathrm{H}$. Syphilis and HIV seroconversion among a 12-month prospective cohort of men who have sex with men in Shenyang, China. Sex Transm Dis. 2010;37:432-9

45. Zhang JD, Sun YB, Wang S, Liu HJ, Li LJ, Wen YC. HIV and syphilis infections among 121 men who have sex with men in Harbin. Chin J AIDS STD. 2008; 14:69.

46. $\mathrm{Xu} \mathrm{ZH}$. Investigation on AIDS knowledge and behaviors among men who have sex with men in the city of Tieling. Chin J Publ Health. 2009:25:226.

47. Xu H, Hu W, Zhao HY. AIDS survey of MSM homosexuality population in Anshan. Chin J Health Lab Technol. 2009;19:658-713.

48. Sun M, Li D, Jin W, Jiang J, Guan L. Investigation on the infection of HIV, HCV, syphilis and HBV among MSM in Dalian city in 2008. Prev Med Trib. 2009;15:1074-5.

49. Zhao H, Wang G, Liu H. The investigation report of male-to-male contact during the voluntary consulation in Daolin district of Harebin. Guide Chin Med. 2009;7:181-3.

50. Liu S, Wang K, Yao S, Guo X, Liu Y, Wang B. Knowledge and risk behaviors related to HIV/AIDS, and their association with information resource among men who have sex with men in Heilongjiang Province, China. BMC Public Health. 2010;10:250.

51. Ruan Y, Li D, Li X, Qian HZ, Shi W, Zhang X, Yang Z, Zhang X, Wang C, Liu Y, Yu M, Xiao D, Hao C, et al. Relationship between syphilis and HIV infections among men who have sex with men in Beijing, China. Sex Transm Dis. 2007;34:592-7.

52. Liu H, Wang $N$, Zhang $Q$, Shao $Y$, Wu T, Liu $Y$, Jiang HB, Song $Y$, Zhang L, Yin WY. Study of HIV and syphilis infection situation and sexual behavioral characteristics among 416 MSM. Chin J AIDS STD. 2007;13:230-2 234.

53. Zhang X, Wang C, Hengwei W, Li X, Li D, Ruan Y, Zhang X, Shao Y. Risk factors of HIV infection and prevalence of co-infections among men who have sex with men in Beijing, China. AIDS. 2007;21(Suppl 8):S53-SS57.

54. Ruan Y, Luo F, Jia Y, Li X, Li Q, Liang H, Zhang X, Li D, Shi W, Freeman JM, Vermund $\mathrm{SH}$, Shao $Y$. Risk factors for syphilis and prevalence of HIV, hepatitis $B$ and $C$ among men who have sex with men in Beijing, China: implications for HIV prevention. AIDS Behav. 2009;13:663-70.

55. Zhou ZH, Li SM, Liu YJ, Jiang SL, Zhang XX, Li QC, Li DL, Luo FJ, Ruan YH, Shao YM. Study on the relationship between behavioral factors, psychological status and HIV infection among men who have sex with men in Beijing. Chin J Epidemiol. 2010;31:273-6.

56. Wang CH, Yang YH, Lu GJ, et al. Survey of high risk sexual behaviors among men who have sex with men and effect evaluation of behavioral intervention. Chin J Health Lab Technol. 2007;17:2291-2.

57. Ma J, Guo J. Internet survey of high risk sexual behaviors and sexually transmitted diseases among male homosexuals in Tianjin. Mod Prev Med. 2007;34:3928-31.

58. Guo W, Song AJ, Meng HD, Pang L, Rou KM, Wu ZY. Survey on AIDS/STD risk behaviors and prevalence among men who have sex with men in Langfang, Hebei. Chin J Epidemiol. 2008;29:545-7.

59. Guo Y, Zhu XK, Xia JH, Dong XY. Study on HIV/syphilis infections among men who have sex with men and their behavioral feature. Chin J AIDS STD. 2009;15:50-1 71 .

60. Liang L, Chen ZQ, Miao XF, Li BJ, Bai GY, Zhao HR. An investigation of HIV infections among men who have sex with men. Hebei Med J. 2009;31: 1991-2.

61. Qu L, Yang JY, Zhang XG, Tao BY, Yang YR, Bao ZQ. Study on HIV and syphilis infections among men who have sex with men in selected cities of Inner Mongolia. Chin J Epidemiol. 2009;30:1089-90.
62. Wang XL, He JK, Su HH, Cao HZ, Zhang QJ, Zhao GL. HIV and syphilis infection in male homosexuality in Tangshan city. Chin J Publ Health. 2009; 25:787-8.

63. Zhang QJ, Lv WD, He JK, Cao HZ. Analysis of MSM HIV antibody in Tangshan during 2008-2009. Chin J Health Lab Technol. 2010;20:1184-5.

64. Tao ZM, Wang CH, Zeng Q, Guo B, Li GK, Yuan HJ. HIV serology examination analysis among 169 men who have sex with men. Med Inf. 2010;23:288-9.

65. Yang ZF, Fang SN, Cai WD, Duan LH. Survey on syphilis and HIV infection and sexual behavior among men having sex with male. Chin J Publ Health. 2003;19:1292-3.

66. He Q, Wang $Y$, Lin $P$, Zhang ZB, Zhao QQ, Xu HF. KAP study on AIDS among men who have sex with men in Guangzhou, Guangdong Province. Chin J Dis Control Prev. 2005;9:106-8.

67. Tao XY, Cai WD, Cai YM, Wei AY, Huang GW, Song D. Survey of related high risk sexual behaviors of MSM in Shenzhen city. Mod Prev Med. 2004;31:2478.

68. He Q, Wang Y, Lin P, Liu Y, Yang F, Fu X, Li Y, Sun B, Li J, Zhao X, Mandel J, Jain S, McFarland W. Potential bridges for HIV infection to men who have sex with men in Guangzhou, China. AIDS Behav. 2006;10:S17-23.

69. Cai WD, Fen TJ, Tan JQ, Chen L, Shi XD, Chen PL, Jian LZ, Tao XY. A survey of the characteristics and STD/HIV infection of homosexuality in Shenzhen. Mod Prev Med. 2005:32:328-30.

70. Li N, Wang Z, Sun D, Zhu Q, Sun G, Yang W, Wang Q, Nie Y, Wu Z. HIV among plasma donors and other high-risk groups in Henan, China. J Acquir Immune Defic Syndr. 2010;53(Suppl 1):S41-SS47.

71. Feng TJ, Liu XL, Cai YM, Pan P, Hong FC, Jiang WN, Zhou H, Chen XS. Prevalence of syphilis and human immunodeficiency virus infections among men who have sex with men in Shenzhen, China: 2005 to 2007. Sex Transm Dis. 2008;35:1022-4.

72. Hong FC, Zhou H, Cai YM, Pan P, Feng TJ, Liu XL, Chen XS. Prevalence of syphilis and HIV infections among men who have sex with men from different settings in Shenzhen, China: implications for HIV/STD surveillance. Sex Transm Infect. 2009;85:42-4.

73. Weng YQ, Bai Y. Surveillance on the high risk behaviors among 239 men who have sex with men. J Appl Prev Med. 2009;15:152-3.

74. Lan GH, Liu W, Zhu QY, Fu X, Huang YM, Zhou Y. To analyze the surveillance results of immigrant MSM in Guangxi. Appl Prev Med. 2009;15:168-70.

75. Wen F, Zong F, Cheng WB, Gao K, Luo BL, Xu HF. HIV and current syphilis prevalence and related factors among men who have sex with men in Guangzhou. S Cn J Prev Med. 2010;36:19-23.

76. Zhong F, Lin $\mathrm{P}$, Xu H, Wang $Y$, Wang $M$, He Q, Fan L, Li Y, Wen F, Liang Y, Raymond HF, Zhao J. Possible increase in HIV and syphilis prevalence among men who have sex with men in Guangzhou, China: results from a respondent-driven sampling survey. AIDS Behav. 2011;15:1058-66.

77. Shi WD, Li G, Yang T, Zhou W, Liu PL, Li SL, Chen L, Wei J. Survey of high risk sexual behaviors and HIV, syphilis, HCV among 456 male homosexuals in Wuhan. Med Soc. 2009;22:42-3.

78. Li X, Xing AH, Chang WH, Cui M, Jia H, Ren Q, Lu Y, Wang BS, Zhang JJ. Analysis on AIDS surveillance on MSM in Xi'an, 2003-2008. Chin J Dis Contr Prev. 2009;13:442-4.

79. Li $X$, Xing AH, Wang BS. Analysis of AIDS surveillance data in Shaanxi Province in 2005. Chin J AIDS STD. 2007:13:137-8 155

80. Yang SP, Wang SR, Wang JY, Wang RF, Ayt KLM. Investigation on AIDS knowledge and behaviors among men who have sex with men in Hami prefecture. Endem Dis Bull. 2008;23:49-50.

81. Yang SJ, Mu HT, Li XQ, Li F, Zheng CJ, Zhang ZZ, Duo LK, Li RL, Shi L, Yang CX. Survey of the knowledge, attitude, and practice on AIDS among MSM population in Urumchi. Mod Prev Med. 2007;34:4624-5.

82. Zhang Y, Liu JW, Ni MJ, Dong YH. Laboratory study on detective results of male homosexuality population in Urumqi, Xinjiang. Endem Dis Bull. 2008; 23:26-8.

83. Qiao XW, Ma XZ, Li Y. Epidemiological analysis of HIV-VCT service among men who have sex with men in the city of Lanzhou in 2008. Health Vocat Educ. 2009;27:104-5.

84. Zhang M, Wang XD, Yang Y. Prevalence of HIV, anti-HCV, syphilis infection and AIDS knowledge among men who have sex with men (MSM) in Urumgi. Chin J Public Health. 2009;25:1075-6.

85. Miao ZF, Li J, Lei LM, Han X, Zhang XP. Yinchuan city 312 AIDS related knowledge among MSM and behaviors. J Ningxia. (Medical University). 2009;31:761-2. 
86. He Q, Wu X, Han D, Liang X. HIV infection and risk behavior of men having sex with men in Chengdu city from 2004 to 2007. J Occup Health Damage. 2008;23:222-4

87. Ma AB, An XJ, Yu HF. HIV seropositivity in 78 MSM from Yunnan Provience in 2005. Chin J AIDS STD. 2007;13:60-1.

88. Lu CG, Yuan F, Shi Z, Yang JZ, Li XY, Gao L, Li X, Hu SY. The study of HIV infection and KABP about AIDS among the MSM in Guiyang city. Guizhou Med J. 2006;30:202-4.

89. Lu CG, Yuan F, Shi ZH, Yang JZ, Li XY, Gao L, Lu X, Hu SY. HIV infection survey among MSM. Chin J Public Health. 2006;2:1320-1.

90. Jia M, Luo H, Ma Y, Wang N, Smith K, Mei J, Lu R, Lu J, Fu L, Zhang Q, Wu Z, Lu L. The HIV epidemic in Yunnan Province, China, 1989-2007. J Acquir Immune Defic Syndr. 2010;53(Suppl 1):S34-SS40.

91. Zhou J, Zhu JJ, Bin H, Zhang L, Yao M, Zhang W, Zhang W, Zhong Y, You QY, Gao L. A survey of HIV/STD, HBV and HCV infections and risk behaviors among MSM in two central districts of Guiyang city. Chin J AIDS STD. 2008;14:47-8 51.

92. Lu CG, Yang JZ, Yuan F, Li XY, Shi ZH, Hu SY. A study among MSM from a region of Guizhou Province. Guizhou Med J. 2007;31:462-3.

93. Feng Y, Wu Z, Detels R, Qin G, Liu L, Wang X, Wang J, Zhang L. HIV/STD prevalence among men who have sex with men in Chengdu, China and associated risk factors for HIV infection. J Acquir Immune Defic Syndr. 2010; 53(Suppl 1):S74-SS80.

94. Feng L, Ding X, Lu R, Liu J, Sy A, Ouyang L, Pan C, Yi H, Liu H, Xu J, Zhao J. High HIV prevalence detected in 2006 and 2007 among men who have sex with men in China's largest municipality: an alarming epidemic in Chongqing, China. J Acquir Immune Defic Syndr. 2009;52:79-85.

95. Xiao Y, Ding X, Li C, Liu J, Sun J, Jia Y. Prevalence and correlates of HIV and syphilis infections among men who have sex with men in Chongqing municipality, China. Sex Transm Dis. 2009;36:647-56.

96. Wang Y, Zhang HB, Gui ZG, Yang HW, Fan J, Zheng YJ, Liu L. Analysis of behavior of MSM population and the biological monitoring result in Mianyang city. Mod Prev Med. 2008;35:3780-3 3789.

97. Zhou SJ, Pan CB, Meng XR, Chen GQ, Zhang BC. The related research on sexual behavior and HIV infection in MSM of Chongqing. Chin J Infect Control. 2008;7:381-4 380.

98. Liang ZM, Chen SH, Gong YH. Study on epidemiologicai situation and control strategies of HIV/AIDS among men who have sex with men in Foshan from 2008 to 2010. J Med Pest Control. 2011;27:419-42.

99. Yang $L G$, Song XP, Ding XP, Sun L, Duan Y, Fan P. Study on AIDS knowledge,behavior and HIV infection among MSM in Fuyang of Anhui Province. Anhui J Pre Med. 2012;18:22-7.

100. Chen W, Zhou Y, Jiang W, Wen XQ, Zhang ZK. Monitoring of HIV/AIDS among MSM in Guilin city, Guangxi in 2010. Cn Trop Med. 2012;12:58-60.

101. Huang HY, Zhang XP, Li J, Hu ZW, Li ZR. Studies on the HIV, syphilis and hepatitis $C$ infection and sexual behavior characteristic among men who have sex with men in Hefei. Mod Prev Med. 2011;38:1933-8.

102. Wang KL, Yan HM, Zhao DH, Luo JL, Hui S, Tong X. Infection status of HIV, syphilis,and HCV and its influence fact ors in MSM in four cities of Heilongjiang Province. Chin J Prev Med. 2009;10:906-9.

103. Lu L, Xu D, Qiu HH, Yan H, Chen RC. Investigation on STDs/AIDS infection among MSM in Nanchang. J of Pub Health and Prev Med. 2011;22:45-6.

104. Chen SH, Yang NH, Zhou J. Survey on the MSM group of knowledge and related HIV/AIDS characteristic and STD/HIV infection in Nanning. Mod Prev Med. 2010;37:3928-32.

105. Bao YG, Zhang YH, Zhao JK, Sun JP, Tan HZ. HIV infection and KAP status among men who have sex with men in 14 Chinese cities. Zhonghua Yu Fang Yi Xue Za Zhi. 2009;43:981-3.

106. Chen X, Zhang J, Huan XP, Rong ZX, Yu RB, Yang HT. A analysis of the high risk behaviors, HIV Infection and related factors among men who have sex with men in Yangzhou, Jiangsu Province. Acta Universitatis Medical Nanjing (Natural Science). 2012;32:479-86

107. Li CM, Xiao Y, Liu JB, Ding XB, Jia Y. HIV and syphilis infections among men who have sex with men in Chongqing municipality, China. Zhonghua Liu Xing Bing Xue Za Zhi. 2009;30:126-30.

108. Liu YY. Study on HIV, HCV and syphilis infection in men who have sex with men and their demographic characteristic, Changsha. Med Prac Prev. 2012; 17:788-90

109. Qu L. Prvalence of HIV infection and its assoiated factors among 805 MSM in Inner Mongolia. Prac Prev Med. 2011;18:2081-3.

110. Chen H, Luo W, Li Y, Li ZY. Prevalence of HIV and syphilis infection in 831 MSM. J Dermatol Venereol. 2011;33:236-7.
111. Zhou C, Ding XB, Feng LG, Guo XX, Han M. Study on the prevalence and associated factors of HIV and syphilis among 1166 men who have sex with men. Mod Prev Med. 2011;38:815-20.

112. Han H, Zhao QY, Chen XW, Zhang XP. Survey on HIV/AIDS knowledge, high-risk behaviors and HIV infection among men who have sex with men in Taiyuan City. Taiyuan, 2012. Prev Med Trib. 2012;18:497-501.

113. Jie T, Zhang ZK, Jiang W, Zhou Y. Survey on AIDS-related knowledge, behavior and HIV and syphilis infection among men who have sex with men in Guilin city. Pre Med Tri. 2012;18:431-4.

114. Xu JJ, Reilly KH, Lu CM, Ma N, Zhang M, Chu ZX, Wang JJ, Yun K, Shang H. A cross-sectional study of HIV and syphilis infections among male students who have sex with men (MSM) in Northeast China: implications for implementing HIV screening and intervention programs. BMC Public Health. 2011;11:287

115. Bai H, Huan X, Tang W, Chen X, Yan H, Liu X, Yang H, Peng Z, Zhao X, Yu R, $\mathrm{Yu} H$, Chen F. A survey of HIV infection and related high-risk factors among men who have sex with men in Suzhou, Jiangsu, China. J Biomed Res. 2011 25:17-24.

116. Fan S, Lu H, Ma X, Sun Y, He X, Li C, Raymond HF, McFarland W, Sun J, Ma W, Jia $Y$, Xiao Y, Shao Y, et al. Behavioral and serologic survey of men who have sex with men in Beijing, China: implication for HIV intervention. AIDS Patient Care STDs. 2012;26:148-55.

117. Liao M, Kang D, Jiang B, Tao X, Quin Y, Wang T, Bi Z, Xiao Y, Li C, Wu P, Vermund $\mathrm{SH}$. Bisexual behavior and infection with HIV and syphilis among men who have sex with men along the east coast of China. AIDS Patient Care STDs. 2011;25:683-91.

118. He Q, Wang Y, Lin P, Raymond HF, Li Y, Yang F, Zhao J, Li J, Ling L, McFarland W. High prevalence of risk behaviour concurrent with links to other high-risk populations: a potentially explosive HIV epidemic among men who have sex with men in Guangzhou, China. Sex Transm Infect. 2009; 85:383-90.

119. Chow EP, Chen L, Jing J, Gao L, Zhang J, Wilson DP, Zhang L. HIV disease burden and related risk behaviours among men who have sex with men in Yuxi prefecture, Yunnan Province, China: 2010-2011. AIDS Behav. 2013;17: 2387-94.

120. Zheng J, Wu Z, Poundstone KE, Pang L, Rou K. HIV, syphilis infection, and risky sexual behaviors among male university students who have sex with men in Beijing, China: a cross-sectional study. AIDS Educ Prev. 2012;24:78-88.

121. Wei AW, Zhang JL, Ma ZL. Analysis on AIDS, syphilis and HCV infection results among MSM people. J Med Pest Control. 2011;27:727-32.

122. Zhang L, Ding X, Lu R, Feng L, Li X, Xiao Y, Ruan Y, Vermund SH, Shao Y, Qian HZ. Predictors of HIV and syphilis among men who have sex with men in a Chinese metropolitan city: comparison of risks among students and non-students. PLoS One. 2012;7:e37211.

123. Zhang XJ, Yu JP, Li M, Sun X, Han Q, Li M, Zhou F, Li X, Yang Y, Xiao D, Ruan $Y$, Jin Q, Gao L. Prevalence and related risk behaviors of HIV, syphilis, and anal HPV infection among men who have sex with men from Beijing, China. AIDS Behav. 2013;17:1129-36.

124. Zhang Y, Chen P, Lu R, Liu L, Wu Y, Liu X, Zhao Z, Yi D. Prevalence of HIV among men who have sex with men in Chongqing, China, 2006-2009: cross-sectional biological and behavioural surveys. Sex Transm Infect. 2012; 88:444-50.

125. Zhang L, Zhang D, Yu B, Wang S, Liu Y, Wang J, Li X, Shang X, Li H. Prevalence of HIV infection and associated risk factors among men who have sex with men (MSM) in Harbin, P. R. China. PLOS ONE. 2013;8:e58440.

126. Zou H, Wu Z, Yu J, Li M, Ablimit M, Li F, Pang L, Juniper N. Sexual risk behaviors and HIV infection among men who have sex with men who use the internet in Beijing and Urumqi, China. J Acquir Immune Defic Syndr. 2010;53(Suppl 1):S81-7.

127. Wang FH, Cheng XL, Xiao YK, Su B, Ji G. Analysis of the results of HIV/AIDS surveillance among men who have sex with men in Anhui Province in 2009-2010. Chin J Dis Contr Prev. 2011;15:685-8.

128. Gao YJ, Yu MR, Li SM, Zhang Z, Li DL, Yang L. Prevalence and predictors of HIV syphilis and herpes simplex type 2 virus (HSV-2) infections among the men who have sex with men (MSM) in Beijing. Chin J Public Health. 2012;28:451-3.

129. Zhou YQ, Gao J, Gu KK, Wang H, Ma XL. Testing of HIV and syphilis and investigation of risk factors among 416 MSM. Chin Prim Health Care. 2012; 26:72-4.

130. Ou Y, Feng L, Ding X, Zhao JK, Xu J, Han M, Zhou C. A respondent-driven sampling survey on HIV and risk factors among men who have sex with men in Chongqing. Chin J Epidemiol. 2009;30:100-4. 
131. Meng X, Xie CM, Zeng XP. Investigation on AIDS and STD affection in MSM of Changde. J Trop Med. 2010;10:884-5.

132. Tang M. Study on the behaviors and related diseases in men who have sex with men in Dazhou. J Occup Health Damage. 2012;27:314-5.

133. Sun ML, Kong Y, Jiang J. Dalian city MSM about HIV, HBV, HCV and syphilis infection investigation. J Disease Monitor Control. 2012;12:708-9.

134. Dai LP, Jiang YH, Gong CH. The characteristic of behavior and HIV prevalence among 1315 men who have sex with men in Guangzhou. Chin J AIDS STD. 2011;17:35-6.

135. Mou C, Wang Q, Zhong Y, Jiang Y, He Z. Correlation between HIV antibody and sexual behaviors of men who have sex with men in Guangzhou in 2010. Nan Fang Yi Ke Da Xue Xue Bao. 2012;32:113-5.

136. Shi XD, Liu SZ, Zhao J. Comparisons of sexual behavor and infection of HIV and syphilis among men who have sex with men in Shenzhen, Guangzhou. S Cn J Prev Med. 2010;36:22-5.

137. Wang WM, Xue LJ, Chen YQ. Syphilis/HIV infection and KAP status among MSM in Kunshan City. Prev Med Trib. 2011;17:396-8.

138. Sun DY, Ma YM, Nie YG, Zhu Q, Wang Z. Study on HIV/HCV and syphilis infection among MSM in two cities. Chin J Pract Med. 2010;37:10-2.

139. Chen JJ, Liu J, Li Y, et al. Survey on HIV/syphilis infection and characteristic of MSM. Chin J AIDS STD. 2011;17:328-31.

140. He SX, ZHAN HD. Survey on characteristic and infection of HIV/syphilis in Geemu city, Qinghai Province. Qinghai Medicine. 2012;42:87-8.

141. Gong CL, Zhang QH. Results of AIDS monitoring of 252 MSM in Quanzhou city. Cn Trop Med. 2010;10:1496-7.

142. Zhang Q, Deng P, Geng YJ. Study on HIV/syphilis infections among men who have sex with men and their behavioral feature. Cn Trop Med. 2012;12:219-20.

143. Pan P, Cai Y, Hong F, et al. Investigation on high risk behavior and HIV/ syphilis infection among 675 men having sex with men (MSM) in Shenzhen City. J Pub Health Prev Med. 2012;23:21-3.

144. Cai YM, Hong FC, Feng TJ, Wen LZ, Zhang CL. Distribution characteristics and influencing factors of syphilis among men who have sex with men in Shenzhen. Chin J AID STD. 2013;19:125-6.

145. Wang L, Song W, Wang XL. Survey on the knowledge, high risk behavior and HIV/syphilis infection rate among men who have sex with men of site and online types in Shenyang. Chin J Dis Control Prev. 2010;14:1193-6.

146. Wang YY, Yang HT, Li SK. Investigation of acquired immunodeficiency syndrome correlated with knowledge, attitude, high risk behaviors and HIV/ syphilis infection in MSM population in Shijiazhuang in 2008. Mod Prev Med. 2011;38:3958-60.

147. Wang YY, Chen JY, Li Y, Gu L, Zhao A. Investigation on AIDS prevalence among men who have sex with men in Lanzhou city. Chin J Nat Med. 2010;12:327-9

148. Zhang F, Zhao X, Cao X. Sero-prevalence and correlates of HIV infection among men who have sex with men in Suzhou. Chin J Dis Control Prev. 2011;15:1031-4.

149. Xu Y, Zhang $X$, Zhu Z, Pan L, Yu MR. Analyses of the prevalence of HIV infection in MSM in Taizhou city. Jiangsu J Prev Med. 2012;23:50-1.

150. Wang XD, Ma Y, Yang Y. Study of the prevalence of HIV, syphilis and HCV in MSM in Urumqi. J Dermatol Venereol. 2011;33:104-5.

151. Liu PL, Yao ZZ, Shi WD, Ding J, Li SL, Chen L, Yang T, Wang X, Zhou W. Epidemiological study on the status of HIV/STD among MSM in Wuhan City. Chin J Dis Control Prev. 2010;14:917-9.

152. Zhang ZF, Xu N, Zhao CC, Gao XY, Li YZ. Survey on the prevalence of HIV, HCV and syphilis infection from different population in Xining. J Med Pest Control. 2011;27:1017-8.

153. Wang ZJ, Sun L, Ma X. Survey on AIDS/STD risk behaviors and prevalence among men who have sex with men in Guangling, Yangzhou. Jiangsu Journal of Preventive Medicin. 2010;21:4-7.

154. Chen KJ, Zhao XY, Chen L, Zou J, Li Q, Teng G, Ding X. Analysis on prevalence of HIV and syphilis and its risk behavior characteristics among men who have sex with men in Yongchuan district of Chongqing. Chongqing Medicine. 2012;41:1730-3.

155. Yang GZ, Wang H, Shi JC. Survey of HIV/TP infection of gay in Dali prefecture. Chin J Health Lab Technol. 2011;21:995-6.

156. Luo H, Mei J, Song L, Lu R, Lu JY, Fu LR, Li XH, Jia MH, Lu L. Comprehensive surveillance on HIV among 1237 men who have sex with men in thirteen cities of Yunnan. Chin J Epidemiol. 2012;33:706-9.

157. Xu J, Han DL, Liu Z, Ma XY, Wang LL, Pang L, Zhang HB, Wu ZY. The prevalence of HIV infection and the risk factors among MSM in 4 cities, China. Chin J Prev Med. 2010;44:975-80.
158. Ding XB, Feng LG, Chen $Y$, et al. Study on the prevalence and related factors of HIV infection in MSM in a rural country in Chongqing. Chin J Prev Med. 2010;44:273-5.

159. Ding XB, Feng LG, Xu J, et al. Study on the prevalence of HIV, syphilis, HCV and HSV-II and its associated factors among 743 men who have sex with men in Chongqing. Chin J Dis Control Prev. 2012;14:227-31.

160. Feng LG, Ding XB, JO XU, Ou YL, Xu SM, Zheng JQ, Guo XJ, Yang MF, Liu $X P$. Study on HIV, syphilis and HCV prevalence and its associated factors among internet MSM comparison to non-internet MSM in Chongqing. J Trop Med. 2010;10:78-82.

161. Guo HJ, Feng D, Yi L, et al. Infection status of HIV, syphilis, HCV among MSM and their behavioral characteristic in Zunyi city. Occup Health. 2012;28:4401.

162. Wu GF, Shi TT. Survey on HIV, syphilis, and health requirement from 2010 to 2012. Guide Chin Med. 2013;34:570-1.

163. Chen SX, Zhang ML, Han XM. Study on HIV knowledge and its associated factors among internet MSM in Gaomi from 2011 to 2012. Prev Med. 2013; 25:410-1.

164. Shi YH, Liu L, Liu W, Shu HP. The analysis report of Pingxiang city gay AIDS and venereal disease sentinel surveillance results. J Dis Monit Control. 2014; 8:279-81.

165. Tang YL, He FN, Liu J, Kong FY. Analysis on the risk behavior characteristics among men who have sex with men in Jiujiang. S Cn J Prev Med. 2014;40: $161-3$.

166. Ju CW, Li XH, Ju WL, et al. Analysis of HIV infection and the risk factors among MSM in Guigang. Applied Prev Med. 2014;20:206-11.

167. Jin J, Luo Y, Chen JF, et al. HIV infection status and associated risk factors among men who have sex with men in Hangzhou, Zhejiang. Dis Surveill. 2015;30:639-43.

168. Pan YF, Wang DL, Wang JT. Analysis of samples from different sources in sentinel surveillance among men who have sex with men in Changzhou. Jiangsu J Prev Med. 2015;26:33-6.

169. Zhu C, Hua Y, Chen X, Wang JM. Analysis of HIV infection among 253 men who have sex with men. J Aerosp Med. 2015;26:882-3.

170. Wang SL, Guo NY, Hu XM. HIV infection status and its influencing factors among MSM in Urumqi. Chin Gen Practice. 2015;18:1260-4.

171. Zheng LX, Que JC, Chen QJ, Yan JP. Monitoring and analysis of HIV infection and behavior of MSM in Longyan. Chin J Lepr Skin Dis. 2015;3:39-41.

172. Qin Y, Bi XJ, Tang XF, Liu BL, Yang EZ, Tang W. Analysis of HIV infection among men who have sex with men in Hechuan from 2009 to 2013. Med Peop1e. 2014;27:1-2.

173. Ye HS, Guo HG, Li ZM. An analysis on the prevalence of HIV/syphilis infections and the related risk behaviors among 297 men who have sex with men from gay internet community in Zhuhai city. J Diagn Ther Dermatol-Venereol. 2014;21:151-4.

174. Ding W, Zhang YX. Survey on knowledge, attitude and practice about HIV/ syphilis among MSM, Qingzhou city, 2013. Prev Med Trib. 2014;20:112-4.

175. Chen Y, Sun XF, Hu JL, Wang Y. Analysis on the prevalence of HIV and associated risk factors among men who have sex with men in Huaian. Jiangsu Health Care. 2014;16:1-2.

176. Zhou XH, Yan J, Fei YH, Jiang J. Survey on infection status of HIV, syphilis, HCV among 169 MSM and their behavioral characteristic in Lianshui. Jiangsu Health Care. 2014;16:22-3.

177. Xu YL, Yang XS, Liu KY. Prevalence of and associated factors for HIV and HBV infections among men who have sex with men in Beijing, China. J Capit med Univ. 2014;35:96-100.

178. Ma XY, Mc Farland Willi ZQY. Zhang Q. analysis on trend of HIV prevalence among men having sex with men. Chin J Public Health. 2007;23:1352-4.

179. Wang W, Zou YZ, Hao XG. Survey on the prevalence of HIV/syphilis and associated factors among men who have sex with men. Zhejiang Prev Med. 2013;25:43-4.

180. Yang Y, Xia B. Characteristics of heterosexual behaviors and HIV/syphilis infection among men who had sex with men (MSM) in Chaoyang District, Beijing. Chronic Pathemathol J. 2013:194-6.

181. Zhang X, Zhou J, Huang X, Zhang P, Chen JR, Gu CH. Investigation of HIV infection and SEX behaviors among MSM in Pudong district, 2008-2012. Med Soc. 2013;26(26):51-2.

182. Wu P. Survey on infection status of HIV, syphilis, HCV among MSM and their behavioral characteristic in Wuxi. Jiangsu Health Care. 2013;15:4-5.

183. Xiao L, Wang B, Wang J, Yu WX. Analysis of HIV, syphilis, HCV infection among men who have sex with men. J Dermatol Venereol. 2013;35:112-8. 
184. Li SJ, Li JF, Liu LH, Zhao C, Zhou H. Survey on infection status of HIV/syphilis among 450 MSM in Shijiazhuang. Hebei Med J. 2013;35:129-30.

185. Tan WQ, Zhao JS, Liu ZS, Zheng J, Huang ZL, Chen X. HIV prevalence trend of men who have sex with men from National Sentinel Surveillance in Changsha: 2012 2014. Prac Prev Med. 2015;22:912-4.

186. Guan W, Zhu Y, Wei Q, Wu X, Li L, Yan H, Yang M, Chen L. Trends on the changing prevalence in patients with early syphilis and HIV infection among men who having sex with men in Nanjing, from 2008 to 2013. Zhonghua Liu Xing Bing Xue Za Zhi. 2015;36:624-8.

187. Jia XW, Luo Q, Wang F, Tang ZM, Sui GZ. Study on HIV infection and HIV knowledge among MSM in Beichuan Qiang Autonomous County, Mianyang city. Prac Prev Med. 2015;27:467-9.

188. Zhao LH, Jiang A, Zhang YH, Wang XM. Study on incidence of HIV and its influencing factors among MSM in Ningxia. Chin J Venereol. 2015;29:50-2.

189. Peng T, Peng G, Yang K, Jiang H, Chen H, Tang H, Chu X, Liu C. Recent HIV infection among men who have sex with men in Hubei, 2010-2013. Zhonghua Liu Xing Bing Xue Za Zhi. 2015;36:162-6.

190. Zhu ZP, Zhang M, Liu L, Xu YY, Xu WJ. An analysis of new HIV infection in MSM in Nanjing city in 2013. Chin J AIDS STD. 2015;21:41-3.

191. Mei L, Chen XW, Zhao QY, Han H, Han T. Survey of sexual behavior characteristics, HIV infection status and sexually transmitted disease prevalence among men who have sex with men in Taiyuan, Shanxi, 2013. Dis Surveill. 2014;29:776-81.

192. Feng YJ, Wang L, Wang ZG, He YL, Wang L, Zhang J. The situation and influence factors of HIV/TP/HCV infection in men who have sex with men in Qinhuangdao. Chin J AIDS STD. 2014;20:748-50.

193. Hui S, Li Y, Yan H, Guo W, Tong X, Wang K. HIV incidence and factor related to lost-to-follow-up among men who have sex with men in Harbin, Heilongjiang. Chin J Epidemiol. 2015;36:1381-3.

194. WP HE, Ye XD, Tang SK, Zhuang JT. The prevalence of HIV and syphilis and related factors among men who have sex with men in Guangzhou. Chin Prev Med. 2015;16:684-8.

195. Zhao WB, Su QJ, Jiang CH. Prevalence and influencing factors of HIV infection among MSM in An'shan City from 2012 to 2014. Occup Health. 2015;31:3120-5.

196. Wang ZH. Survey of HIV infection in men who have sex with men (MSM) in Jinzhou. Chin J Convalescent Med. 2015;24:1220-2.

197. Chen SL, Wu WJ. An analysis on HIV infection status and related factors among men who have sex with men. Zhejiang Prev Med. 2015;27:992-8.

198. Wei W, Li LM, Cao WH, Lv JJ, Chu XY. Survey on risk factors of HIV infection among men who have sex with men (MSM) in Haidian district, Beijing. Cap J Public Health. 2015;9:198-202.

199. Zhao YY, Qiu XQ, Cui DY. Analysis of HIV infection and the influencing factors among MSM in Xiangyang. China Trop Med. 2015;15:1083-5.

200. Liu JH, Yuan ZK, Liao QH, Gong ZH. Analysis on HIV/AIDS sentinel surveillance among the group of men who have sex with men from 2013 to 2014 in Jiangxi Province. Soft Sci Health. 2015;29:576-8.

201. Wu P. Wuxi MSM population of HIV infection situation analysis and intervention methods. World Latest Medicine. 2015;15:55-6.

202. Luo QS, Zhao J, Chen L, Liu SC, Zhang Y. Prevalence and influencing factors of HIV infection among MSM in Shenzhen. China Trop Med. 2015;15:815-8.

203. Chen CY, Li L, Wang M, Lai XH, Sun YM, Chen JH, Wang T. Analysis of the HIV infection and its related behaviors among men who have sex with men in Zhongshan city (2010-2014). J Pub Health Prev Med. 2015;26:12-5.

204. Tang HL, Hu YQ, Zhang T. A cohort study of new HIV infections among men who have sex with men in Jinhua, Zhejiang Province. Chin Rural Health Serv Admin. 2015;35:477-80

205. Zhang XX, Xue FH, Yi-hua J, Zeng DF. Surveillance and analysis of HIV/ syphilis among men who have sex with men in Lucheng district during 2011-2013. Chin J Health Lab Tec. 2015;25:1073-6.

206. Chen LF, Tang XL, Chen Z. Epidemic situation of HIV/AIDS among men who have sex with men in different places in Sanya. China Trop Med. 2015;15:322-4.

207. Zhang WY, Zhang RZ, Wang J, et al. HIV infection and its influential factors among men who have sex with men in Kunming. Chin J Dis Control Prev. 2015;19:203-5.

208. Sui DD, Chen SH, Gong YH, Zhong LQ, Zeng Q. HIV/AIDS sentinel surveillance among men who have sex with men in Foshan city, 2009-2013. S Cn J Prev Med. 2015;41:33-6.

209. Ma YM, Li N, Sun DY, Nie YG, Li J, Wang Z. HIV infection status among men who have sex with men in Henan, 2008-2013. Zhonghua Liu Xing Bing Xue Za Zhi. 2015;36:158-61.
210. Xu JL. Prevalence of HIV infection among MSM in Chaoyang city in 2012. Chin J Public Health. 2015;31:118-9.

211. Chen JJ, Wang YH, Niu JP, Li Y, Gu LP. Epidemiological survey of HIV/AIDS among MSM in Lanzhou in 2006-2013. Chin J Prev Med. 2014;15:649-53.

212. Long QS, Lin P, Li Y, Fu XB, Liu J, Ye R, Li J, Huang H. Prevalence of human immunodeficiency virus and associated risk factors among men who have sex with men in the major regions of Pearl River Delta, from 2009 to 2013. Zhonghua Liu Xing Bing Xue Za Zhi. 2014;35:1227-30.

213. He SF, Sui YM, Li GY, Ma XY, Lu HY, Zhang G, He X. HIV infection status and its influence factors in men who have sex with men (MSM) in Beijing from 2009 to 2013. Chin J Prev Med. 2014;15:161-4.

214. Yang $\mathrm{QW}$, Jing $\mathrm{ZC}$, Su YY. Prevalence and risk factors of HIV infection in MSM population in Mengzi, Yunnan. Chin J Health Educ. 2014;30:716-9.

215. Jin Y, Li JZ, Hu YX, Zhu YW, Xu LF, Yang H. HIV infection status and related risk factors in men who have sex with men in Jinan, Shandong. Dis Surveill. 2014;29:638-42.

216. Li J, Yu AL, Yang CM, Wang B, Yang MY, Meng L. Situation and correlated behavior of HIV infection among currently married MSM in Gansu province. Zhonghua Liu Xing Bing Xue Za Zhi. 2014;35:809-11.

217. Tao LD, Gao Y, Shi L. Epidemiological analysis of HIV/AIDS and syphilis in 801 MSM in Chengguan District of Lanzhou. Bull Dis Control Prev. 2014;29:10-2.

218. Zhao LH, Zhang YH, Wang XM, Ma GM. An analysis on epidemic trend of HIV/AIDS and sexual behavior characteristics among MSM from 2008 to 2012 in Yinchuan city. Chongqing Medicine. 2014;43:2629-31.

219. Wang Y, LL LI, XU J, Li ZJ, Zhang GG. A cohort study of new HIV infections among men who have sex with men in Mianyang city, Sichuan Province of China. Chin J Viral Dis. 2014;4:218-25.

220. Fu ZH, Zhao XP, Cao XP, Zhao YQ, Zhang FX, Shao MC. HIV incidence among men who have sex with men in Suzhou city: a cohort study. Chin J Public Health. 2014;30:726-8.

221. Zhao LY, Zhao N, Zhang HY. A survey on current status of HIV and syphilis infection among men who have sex with men. Chin Prev Med. 2014;15: 253-5.

222. Chen Q, Gui Y, Sun YM, Li Y, Zhang Q, Su XL, Lu HY. HIV infection and syphilis among men who have sex with men in Beijing: a survey in 2012. Chin J Dermatol. 2014;47:349-50.

223. Wei XD, Sui $D$, Yin H. A survey on status of HIV and risk factors among men who have sex with men in Anshan from 2009 to 2011. Pract Prev Med. 2014;21:565-6.

224. Li DM, Ge L, Wang L, Guo W, Ding Z, Li P, Cui Y. Trend on HIV prevalence and risk behaviors among men who have sex with men in China from 2010 to 2013. Zhonghua Liu Xing Bing Xue Za Zhi. 2014;35:542-6.

225. Zhong F, Xu HF, Qin FJ, Cheng WB, Wang M, Ling L. Analysis of HIV prevalence among men who have sex with men in Guangzhou from 2000 to 2010. J Trop Med. 2014;14:353-7.

226. Ouyang L, Wu GH, Zhou Y, Zheng JQ, Zhou QH. Sex behaviors and HIV infection status among men who have sex with men in Chongqing, 20102013. Dis Surveill. 2014;29:124-9.

227. Sun XH, Li XP, Hang XP, Wang Y, Wang P. Investigation on male behavior of Qingyang city crowd HIV/syphilis infection status and influencing factors. Chin J Derm Venereol. 2014;28:165-7.

228. Ma L, Zhou J, Yan F, Qin O, Zhu J, Li J. An analysis of HIV/syphilis infection among men who have sex with men in Guiyang. Chin J Derm Venereol. 2014;28:46-9.

229. Zhao ZJ, Wan YZ, Zhou L, Li DJ, Chang BL. HIV/AIDS sentinel surveillance in men who have sex with men in Dalian, Liaoning, 2009-2012. Dis Surveill. 2014;29:41-3.

230. Shen L, Mao LX, Liu XX, Wang T, Wu X, Yang J. Analysis of HIV, HBV, HCV and syphilis infection among men who have sex with men in Zhenjiang in 2012. Chin J Health Lab Tec. 2014;24:120-1.

231. Bai Y, Li MQ, Tan $L$. Analysis of the result of HIV/AIDS surveillance among men who have sex with men in Liuzhou city from 2007 to 2011. Occup Health. 2013;29:3334-5.

232. Zhang $X$, Cai YM, Song YJ. Prevalence of HIV and syphilis infection among 502 men who have sex with men in Shenzhen. China Trop Med. 2013;13: $1500-7$.

233. Min XD, Wang J, Zhang RZ, et al. HIV prevalence and influencing factors among MSM in Kunming city in 2012. Chin J Public Health. 2013;29:1729-31.

234. QI X, Xu J, Zhang Z, Li SM, Xiao D. Prevalence and incidence of HIV and syphilis among men who have sex men (MSM) in Beijing. Chin Prev Med. 2013;14:407-12. 
235. Wang Y, Li LL, Fan J, et al. Investigation on the sexual behavior and hiv infection among MSM in Mianyang city and analysis of the influencing factors. Prac Prev Med. 2013;20:1166-9.

236. Qian YP, Tao XR, Yang XG. Investigation of the prevalence of HIV and influencing factors among 1378 men who have sex men. J Pathog Biol. 2013;8:921-3.

237. Wang HL, Wang W, Chu HN, et al. Status of HIV and syphilis infection among men who have sex with men in Chengde City from 2011-2012. Occup Health. 2013;29:2521-2.

238. Tian ZW, Zhao SJ, Niu LY, Yang J. Prevalence of HIV/syphilis infection and knowledge, behaviors of STD/AIDS among men who have sex with men in Xuchang city. Chin J Public Health. 2013;29:1330-3.

239. Wu JY. Investigation on new infection rate of HIV-1 among MSM in Qinghai from 2009 to 2011. J Med Pest Control. 2013;29:792-3.

240. Song YJ, Cai YM, Hong FC. Prevalence and factors associated with HIV infection among men who have sex with men in Shenzhen from 2009 to 2011. Cn Trop Med. 2013;13:815-7.

241. Shu B, Situ CM, Liu Y, et al. Analysis of HIV/AIDS sentinel surveillance among msm in Shenzhen. Prac Prev Med. 2013;20:694-6.

242. Han Y, Xia DY, Sun YM. Prevalence and related factors of human immunodeficiency virus (HIV) among men who have sex with men (MSM) in Beijing. Chin J AIDS STD. 2013;19:399-412.

243. Nong QX, Shi J, Xu YF. Prevalence of HIV infection and its risk factors among MSM in Nanning city. Chin J Public Health. 2013;29:682-4.

244. Yan PP, Zhang CY, Liang FF. Study on men who have sex with men for HIV infection prevalence and the incidence in Fujian in 2012. Strait J Prev Medi. 2013;19:1-5.

245. Zhang GQ, Zhao JS, Peng JY, et al. Prevalence of HIV, syphilis infection among men who have sex with men in Changsha, China. Chin J Viral Dis. 2013;3:128-30

246. Feng YJ, Wang ZG, Wang L. The investigation of HIV knowledge and high risky behavior state among men who have sex with men in Qinhuangdao city. Chin J Derm Venereol. 2013;27:271-3.

247. Yang JF, Huan Y, Guo JH, et al. Sexual behavior characteristics and HIV infection status among MSM in Baoshan. J Med Pest Control. 2013;29:244-6.

248. Du GY, Yu HR. Survey on AIDS knowledge, attitude, behavior among men who have sex with men and HIV/syphilis/hepatitis C infection, Liaocheng city, 2010. Prev Med Tri. 2013;19:93-7.

249. Cai YM, Song YJ, Pan P, Hong FC, Feng TJ. An analysis of prevalence of syphilis/HIV in Shenzhen from 2005 to 2011. S Cn J Prev Med. 2013;39:32-4.

250. Jiang WH, He QY, Fan SF. Status and risk factors of HIV infection among MSM in Chengdu. J Prev Med Inf. 2013;29:36-40.

251. Zhou S, Feng LG, Ding XB, Xiong HY. Analysis of HIV infection rate and its influencing factors among male migrant workers who have sex with men. Acta Acad Med Militaris Tertiae. 2013;35:46-9.

252. Yang L, Yang CJ, Chen HC, Ma YL, Mei JY. HIV incidence in MSM in Yunnan, 2008-2011. Mod Prev Med. 2015;42:137-56.

253. Wu XG, Guan WH, Zhu YX. Analysis of HIV infection and risk factors among men who have sex with men in Nanjing district. Jiangsu Med J. 2014;40: 2833-5

254. Wang CC, Liang J, Liu Y, Ma YC, Fan M. A survey on the infection status of HIV, syphilis and HCV among men who have sex with men in Xining. Mod Prev Med. 2014:41:3786-8.

255. Li L, Zhang JY, Liu L, Luo YJ, Pei XD, Hu Y. Infection status of HIV and its influence factors among men who have sex with men in Sichuan Province. Chi J Prev Med. 2014;48:980-4.

256. Hu HY, Zhou LJ, Zhang Z, Yang HT, Liu XY, Fu GF, Huan XP. HIV incidence and its associated factors among men who have sex with men in Jiangsu Province. Chin J Dis Contr Prev. 2014;18:93-6.

257. Lin ZS, Fu CY, Pang Y, Liu CX, Yu JG, Zou G, Chen Y. AIDS knowledge and sexual behavior characteristics and HIV/syphilis infection survey in Qinzhou among MSM. Med Inf. 2014;27:163-4.

258. Zhang H, Yang J, Gao J, Bian ZW, Li CX, Li J, Wang Y, Lai BH. Investigation on HIV prevalence and influencing factors among men who have sex with men in Tianjin city. Mod Prev Med. 2015;42:2620-2.

259. Wang LH, Xu YY, Weng J, Qiu DH, Wu QH, Shen WW, Lin HJ. Cross-sectiona investigation on HIV prevalence and HIV related risk behavior among men who have sex with men in Taizhou. Zhejiang Dis Surveill. 2013;28:362-5.

260. Huang XD, Wei XL, Hui H, Zhao X, Zheng HC, Li JS. Prevalence and risk factors of HIV infection among MSM in Xi'an City. Chin J Dis Control Prev. 2014;18:1044-6.
261. Yan PP, Zhang CY, Ling FF. HIV-1 infection rate and its incidence among men who having sex with men at three cities in Fujian. Strait J Prev Med. 2014;20:1-2

262. Li SJ, Li JF, Liu LH, Zhao C, Zhou H, Wang YY. Investigation on HIV and prevalence among 450 men who have sex with men in Shijiazhuang city. Hebei Med J. 2013;35:129-30.

263. Liu L, Zhang M, Zhu ZP, Wu SS. Analysis on HIV prevalence and related risk factors among men who have sex with men in Nanjing. Jiangsu J Prev Med. 2015;26:33-5.

264. Ji YY, Cheng H, Xu MM. Analysis of surveillance of men who have sex with men at HIV/AIDS sentinels in Wuxi from 2010 to 2013. J Prev Med. 2015;26: 43-5.

265. Ma GL, Ouyang X, Chen JJ, Zheng HN. Monitoring report of HIV infection status among MSM in Xiamen city during 2010 to 2014. Chin J Hosp Stat. 2015;22:37-9.

266. Liu JH, Tang MJ, Jiang N, et al. Analysis of monitoring results of HIV, syphilis, HCV infections in MSM population in Yulin City from 2010 to 2014. J Appl Prev Med. 2015;21:293-5

267. Fu J, Gong ZH, Liao QH. The behavioral characteristics and the HIV prevalence among the men who have sex with men in Jiangxi Province in 2013. Jiangxi Med J. 2014;49:969-72.

268. Ju CW, Li XH, Ju XL, Liang YF. Analysis on HIV/syphilis prevalence and related risk factors among men who have sex with men in Guigang city. Applied Prev Med. 2014;20:206-11.

269. Fu JC, Li SF, Liu XC, et al. Study on HIV disease burden and related risk behaviors among men who have sex with men in Yuxi prefecture, Yunnan Province during 2010-2013. Mod Prev Med. 2014;41:4370-4.

270. Huan XP, Xu JS, Liu XY. Syphilis and HIV infection status among 3348 men who have sex with men in Jiangsu Province. Mod Prev Med. 2013;40:1678-80.

271. Zhang M, Chu Z, Wang H, Xu J, Lu C, Shang H. A rapidly increasing incidence of HIV and syphilis among men who have sex with men in a major city of China. AIDS Res Hum Retrovir. 2011;27:1139-40.

272. Ma X, Zhang Q, He X, Sun W, Yue H, Chen S, Raymond HF, Li Y, Xu M, Du H, McFarland W. Trends in prevalence of HIV, syphilis, hepatitis C, hepatitis B, and sexual risk behavior among men who have sex with men. Results of 3 consecutive respondent-driven sampling surveys in Beijing, 2004 through 2006. J Acquir Immune Defic Syndr. 2007:45:581-7.

273. Liu S, Zhao J, Rou K, Chen L, Cai W, Li L, Wu Z, Detels R. A survey of condom use behaviors and HIV/STI prevalence among venue-based money boys in Shenzhen, China. AIDS Behav. 2012;16:835-46.

274. Cai W, Chen L, Zhao J, Liu G, Shi X. Study on influential factors and characteristics of commercial sex encounters among men having sex with men. J Pub Health Prev Med. 2010;21:53-5.

275. Guo Y, Li X, Fang X, Lin X, Song Y, Jiang S, Stanton B. A comparison of four sampling methods among men having sex with men in China: implications for HIV/STD surveillance and prevention. AIDS Care. 2011;23:1400-9.

276. Xu Y, Li J, Chen S, Li S, Mo J, Zhu J. Investigation of HIV high-risk behavior and infection among men who have sex with men in Nanning. Mod Prev Med. 2009:36:2913-5.

277. Gu L, Li Z, Li Y. Survey of AIDS knowledge knowing rate and risk sex behavior among MSM in Lanzhou. Chin J Derm Venereol. 2007;21:682-3.

278. Cheng W, Zhong F, Wen F, Gao K, Liu J, Luo B, Xu HF, Wang M. Nvestigation of HIV and syphilis infection and AIDS related behaviors among money boys in Guangzhou, China. Chin J Prev Med. 2010;44: 1027-31.

279. Ni Z, Li J, Xu D, Zhou Y, Chen T. An investigation on the infection rate of syphilis and HIV among MSM population from public baths. Zhejiang Prev Med. 2011;23:14-6.

280. Chen S, Zhu J, Li J. Investigation on knowledge of HIV/AIDS and related behavioural characteristics among men who have sex with men in Nanning, Guangxi. Chin J Dis Contr Prev. 2010;14:130-3.

281. Lin A, Yin P, Cai W, Liang Z, Feng T. Survey of risk factors of HIV infection in MSM in Shenzhen City. China Trop Med. 2007;7:168-71.

282. Zhou C. Survey on HIV infection among MSM in Zunyi City. Anhui J Prev Med. 2010;16:211-2.

283. Zhang D, Zhang Y, Li H. Investigation of HIV, syphilis and HCV infection situation and sexual behavioral characteristics among MSM in Ningbo City. Zhejiang Prev Med. 2010;22:1-3.

284. Feng F, Wang Z, Huang S, Lu J, Lin W, Zhong X. Investigation on AIDS knowledge, attitudes and practice characteristics of MSM group and HIV/ syphilis infection situation. Mod Prev Med. 2009;36:2092-3. 
285. Cao G, Guan W, Wu X, Hu H, Shi P, Huan X, Yang HT, Wang N. Study on infection rate of HIV/syphilis among men who have sex with men in a balneary. Acta Univ Med Nanjing. 2007;27:637-40.

286. Wang $H$, Zhang $M$, Hu Q, Ding $H$, Zhao B. Prevalence of HIV/AIDS and risk behavior among men who have sex with men in Shenyang. Chin J Publ Health. 2008;24:995-7.

287. Cai H, Gong C, Dai L, Jiang Y, Weng F, Huang L, et al. HIV and syphilis infection and characteristics of sexual behavior among 435 MSM. Chin J Prev Med. 2010;36:28-30.

288. Chen K, Zheng J, Pan Y, Zhang C, Lin L. Serological surveillance and analysis among men having sex with men in a city of Fujian. China Strait J Prev Med. 2010;16:13-6.

289. Tang L, Wang X, Liu M, Zhu Z, Yang B, Peng J. Related serological surveillance and analysis in 145 men who have sex with men in Wuhan City. Dis Surveill. 2006;21:625-7.

290. Feng L, Ding X, Lu R, Pan CB, Yi HR, Liu HH, Ou YL, Xu J. HIV prevalence and its associated factors among men who have sex with men in Chongqing. Chin J Prev Med. 2008;42:870-4.

291. Li L, Qi J, Liu W. Survey on HIV infection status among men who have sex with men and their behavioral features. Mod Prev Med. 2010;37:2484-6.

292. Shen P, Wang Z, Pan C, Hu G. Analysis of the infection of HIV/syphilis and influence factors of MSM in a certain main district of Chongqing. Chongqing Medicine. 2010;39:956-8.

293. Wang Q, Hou Y, Lian Y. Investigation on the infection of HIV and sexually transmitted diseases in male homosexual population. Strait J Prev Med. 2009;15:11-2

294. Zhang Q, Ding X, Feng $L$, et al. HIV and syphilis infection and related factors among money boys. Acta Academiae Medicinae Militais Tertiae. 2011;33:318-21.

295. Wei S, Zhang H, Xu J, Ma X, Han D, Wang L. Sexual behavior and prevalence of HIV and syphilis among young men who have sex with men. Chin J Publ Health. 2009;26:1479-80.

296. Chen S, Zhou J, Zhu J. Investigation of STI among men who have sex with men in Nanjing City in 2006. Prev Med Trib. 2007;13:772-4.

297. Wang T, Lai X, Li L, Chen C, He B. Survey on AIDS/STD risk behaviors and prevalence among men who have sex with men in Zhongshan. Guangdong Pract Prev Med. 2010;17:1261-3.

298. Cai X. The analysis of risk behavior of MSM in Liaocheng and the serological detection for anti-HIV, anti-TP and anti-HCV antibodies in 2006. Prev Med Trib. 2007;13:888-90.

299. Zhao X, Yang H, He J, Jia S, Yang H, Yao W. Surveillance of AIDS related knowledge awareness, risk behaviors and biology among men having sex with men in Mianyang. J Prev Med Inf. 2010;26:876-8.

300. Wen $X$. The prevalence of AIDS and syphilis infection among the men who have sex with men in Guilin city in 2008. Health World. 2010;4:23-4.

301. Ma Q, Zeng S, Xia S, Pan X, Wang D, Zhu H, Wang H, Jiang T, He L, Zhao D, Peng Z. Risky sexual networks and concentrated HIV epidemics among men who have sex with men in Wenzhou, China: a respondent-driven sampling study. BMC Public Health. 2015;15:1246.

302. Pan X, Wu M, Ma Q, Wang H, Ma W, Zeng S, Chen J, Zhang Y, Miao D, Zhou $X$, Jiang T, He L, Xia $Y$, et al. High prevalence of HIV among men who have sex with men in Zhejiang, China: a respondent-driven sampling survey. BMJ Open. 2015;5:e008466.

303. Zhenhua D, Shuangfeng F, Rong L, Xueqing W, Yaying S, Zhijun L, Weihua J, Fang L, Zhen D, Xiaodong W, Yujing Z, Qinying H. Consistently high HIV prevalence among men who have sex with men in Chengdu city from 2009 to 2014. Int J STD AIDS. 2016;27:1057-62.

304. Lin H, Ding Y, Liu X, Wu Q, Shen W, He N. High prevalence of HIV infection and bisexual networks among a sample of men who have sex with men in eastern China. PLoS One. 2015;10:e0129300.

305. Liu YY, Tao HD, Liu J, Fan YG, Zhang C, Li P, Li LJ, Huang Q, Zhao W, Ye DQ. Prevalence and associated factors of HIV infection among men who have sex with men in Hefei, China, 2013-2014: a cross-sectional study. Int J STD AIDS. 2016;27:305-12.

306. Gao W, Li Z, Li Y, Qiao X. Sexual practices and the prevalence of HIV and syphilis among men who have sex with men in Lanzhou, China. Jpn J Infect Dis. 2015;68:370-5.

307. Zhang SH, Liu SJ, Hu LL, Li JF, Liu LH, Wei N. The prevalence and correlates of syphilis and HIV among homosexual and bisexual men in Shijiazhuang, China. Int J STD AIDS. 2016;27:127-32.

308. Yan H, Ding Y, Wong FY, Ning Z, Zheng T, Nehl EJ, He N. Epidemiological and molecular characteristics of HIV infection among money boys and general men who have sex with men in Shanghai, China. Infect Genet Evol. 2015;31:135-41.

309. Tang W, Babu GR, Li J, Zhang Y, Fu G, Huan X, Tucker JD, Zhao J, Detels R. The difference between HIV and syphilis prevalence and incidence cases: results from a cohort study in Nanjing, China, 2008-2010. Int J STD AIDS. 2015;26:648-55.

310. Mao H, Ma W, Lu H, Wang L, Zheng H, Zhu Y, Peng Z, Yu R, Wang N. High incidence of HIV and syphilis among migrant men who have sex with men in Beijing, China: a prospective cohort study. BMJ Open. 2014;4:e005351.

311. Wang QQ, Chen XS, Yin YP, Liang GJ, Zhang RL, Jiang N, Huan XP, Yang B, Liu Q, Zhou YJ, Wang BX. HIV prevalence, incidence and risk behaviours among men who have sex with men in Yangzhou and Guangzhou, China: a cohort study. J Int AIDS Soc. 2014;17:18849.

312. Zhong F, Liang B, Xu H, Cheng W, Fan L, Han Z, Liang C, Gao K, Mai H, Qin F, Zhao J, Ling L. Increasing HIV and decreasing syphilis prevalence in a context of persistently high unprotected anal intercourse, six consecutive annual surveys among men who have sex with men in Guangzhou, China, 2008 to 2013. PLoS One. 2014;9:e103136.

313. Wang X, Lan G, Shen Z, Vermund SH, Zhu Q, Chen Y, Khoshnood K, Wu Z Tang Z. HIV and syphilis prevalence trends among men who have sex with men in Guangxi, China: yearly cross-sectional surveys, 2008-2012. BMC Infect Dis. 2014;14:367.

314. Zeng G, Feng L, Ouyang L, Lu R, Xu P, Wu G, Lu F. The dynamic trends of HIV prevalence, risks, and prevention among men who have sex with men in Chongqing, China. BioMed Res Int. 2014;2014:602719.

315. Yang HT, Tang W, Xiao ZP, Jiang N, Mahapatra T, Huan XP, Yin YP, Wang XL, Chen XS, Fu GF. Worsening epidemic of HIV and syphilis among men who have sex with men in Jiangsu Province, China. Clin Infect Dis. 2014;58:1753-9.

316. Li X, Lu H, Cox C, Zhao Y, Xia D, Sun Y, He X, Xiao Y, Ruan Y, Jia Y, Shao Y. Changing the landscape of the HIV epidemic among MSM in China: results from three consecutive respondent-driven sampling surveys from 2009 to 2011. Biomed Res Int. 2014;2014:563517.

317. Hong H, Xu GZ, Zhang DD. Prevalence of HIV and sexually transmitted diseases among female and male partners of men who have sex with men in Ningbo, China. Int J Gynaecol Obstet. 2014;125:83.

318. Wu Z, Xu J, Liu E, Mao Y, Xiao Y, Sun X, Liu Y, Jiang Y, McGoogan JM, Dou Z, Mi G, Wang N, Sun J. HIV and syphilis prevalence among men who have sex with men: a cross-sectional survey of 61 cities in China. Clin Infect Dis. 2013;57:298-309.

319. Huan X, Hao C, Yan H, Guan W, Xu X, Yang H, Wang N, Zhang M, Tang W, Gu J. High prevalence of HIV and syphilis among men who have sex with men recruited by respondent-driven sampling in a city in eastern China. Asia Pac J Public Health. 2015;27:NP854-65.

320. Ma XY, Zhang QY, He X, Zhao JK, Li Y, Sun WD, Xu M. Epidemiological study on the status of HIV/STDs and relative behaviors among MSM in Beijing. Chin J Epidemiol. 2007;28:851-5.

321. Han H, Mei L, Che XW, Zhao QY, Han T. Sentinel surveillance of AIDS among men who have sex with men in Taiyuan, Shanxi, 2012. Dis Surveill. 2012;27:964-6.

322. Wang N, Sun YM, Lu HY, Yue H, Han Y, Li XF. HIV prevalence and its impact factors among young men who have sex with men in Beijing. Chin J AIDS STD. 2013;19:241-3.

323. Huang ZL, Shan F, Yan RL, et al. Analysis of HIV/ AIDS high risk behavior and influrencing factors among men who have sex with men in Changsha. Prac Prev Med. 2013;20:1435-8.

324. Wu Q, Cheng W, Zhong F, Xu H, Liu Q, Lin P. HIV infection and syphilis prevalence among men who have sex with men receiving voluntary counseling and testing appointed through a web-based registering system and related factors. Chin J Epidemiol. 2015;36:434-9.

325. Sun LY, Jiang GF, Jiang CZ. Analysis on the AIDS voluntary counseling testing among men who have sex with men from 2008 to 2013 in Jiangdong district of Ningbo. Inter J Epidemiol Infect Dis. 2015;42:214-5.

326. Wang L, Yang N. Survey on knowledge and behavior about HIV/AIDS and HIV infection rate among men who have sex with men of different educational level in Shenyang City. Occup Health. 2015;31:339-41.

327. Zhou BB, Zhu JQ. Analysis on results of HIV voluntary counseling and testing among men who have sex with men in Yinzhou district of Ningbo from 2010 to 2014. Inter J Epidemiol Infect Dis. 2015;42:285-6.

328. Cai YM, Liu H, Song YJ, Hong FC. Factors associated syphilis infection among men who have sex men blood donors in Shenzhen. Chin J Prev Med. 2014;48:128-32. 
329. Zhou W, Wu F, Zhao JJ. Survey of attitude to HIV test and HIV infection status in men who have sex with men in Ningbo, Zhejiang. Dis Surveill. 2014;29:772-5

330. Liao LM, Wang ZG, Ye Z, He YL. Study on high risk behaviors of HIV/ AIDS among 1077 MSM and the prevalence of HIV in Qinhuangdao City. Occup Health. 2014;30:3088-94.

331. Zhong YW, Long QP, Huang ZH. Analysis of syphilis and HIV infection status among MSM in Longgang district of Shenzhen. China Trop Med. 2014;14: 54-6.

332. Zhou JL, Wu SH, Zhou D, et al. Trend analysis on HIV prevalence and highrisk behavior among men who have sex with men in Liaoning Province from 2008 to 2012. Chin J Public Health. 2013;29:1732-4.

333. Li L, Yan HJ, Guan WH, et al. Investigation of HIV and syphilis infection status and analysis of high risk sexual behavior-related influencing factors among MSM in VCT clinics. Jiangsu J Prev Med. 2013;24:8-10.

334. Chang $W H$, Xing AH, Wang BS, et al. Results of sentinel surveillance among MSM in Shanxi Province from 2007-2011. Occup Health. 2013:29:1058-61.

335. Lai YH, Cai YM, Song YJ, Zheng X, Hong FC. Characteristics of high risk behavior and syphilis/HIV infection among MSM in Shenzhen in 2011. China Trop Med. 2013;13:226-7.

336. Lin GQ, Fang BL. Investigation on HIV and syphilis infection among MSM people in Benxi City. Occup Health. 2013;29:2-3.

337. Shi ZH, Zhang GC. Study on the status of 369 cases of MSM crowd AIDS, sexually transmitted infections. Med Inf. 2014;27:71-2.

338. Chen BF, Zhu JQ, Zhang QL, Liu AH. Analysis on HIV/AIDS sentinel surveillance among MSM in Dongguan City in 2010-2012. Pract Prev Med. 2014;21:426-8

339. Wang XM, You SJ. Characteristics of high risk behavior and HIV infect ion among MSM in Nanping city. Strait J Prev Med. 2014;20:19-20.

340. Tan W, Chen L, Liu SC, et al. Analysis of HIV voluntary counseling and testing services in Shenzhen from 2011 to 2013. China Trop Med. 2014;14:689-91.

341. Wu QH, Lin HJ, Xu YY, et al. HIV infection status related knowledge in males visiting sexually transmitted disease clinics in Taizhou. Zhejiang Prev Med. 2015;27:1126-7.

342. Peng TH, Peng GP, Yang K, et al. Epidemiologicalfeatures of newly infected HIV male who have sex with male in Hubei Province (2010-2015). J of Pub Health and Prev Med. 2017;28:49-52.

343. Zhang X, Zhang WL, Song BY, et al. Analysis of HIV and syphilis infection and high-risk behaviors among men who have sex with men during 2010 2015 in Xichang City of Sichuan Province. J Prev Med Inf. 2017:33:301-6.

344. Xu YY, Zhu ZP, Wu SS, et al. Infection status of HIV in MenWho have sex with men in Yin chuan, China, 2011-2015. Chinese Journal of Virology. 2017; 33:367-71.

345. Wang LH, Zhou LL, Li DD. HIV and syphilis incidence status and its risk factors among men who have sex with men in Jiangmen City of Guangdong Province in 201 1-2015. J Diagn Ther Dermato-Venereol. 2016;23:272-9.

346. Yang $H$, Ye L, Su L, et al. An analysis on incidence of HIV-1 epidemics among men who have sex with men in Sichuan Province during 20112015. Chin J Prev Med. 2019;53:327-9.

347. Li L, Cao XP, Chen YH, et al. Prevalence trend and influential factors of HIV incidence among men who have sex with men in Suzhou from 2011 to 2015. Jiangsu J Prev Med. 2018;129:484-7.

348. Lin L, Chen L, Zheng WX. HIV and syphilis detection among MSM attending HIV voluntary counseling and testing, Fuzhou city,2012-2013. Prev Med Trib. 2016;22:525-9.

349. Liu BX, Huang DP, Li YJ. Prevalence of HIV infection and related risk factors among MSM in Changde City. Pract Prev Med. 2017;24:316-9.

350. Duan ZH, Fan SF, Shi YY. HIV incidence and recent HIV testing among men who have sex with men, Chengdu. Mod Prev Med. 2017;44:914-21.

351. Yan S. Analysis on the results of AIDS sentinel surveillance among men who have sex with men in Fushun City from 2011 to 2015. Contemp Med. 2017; 23(31):474-5.

352. He HL, Zhu KX, Xu MZ. An investigation of HIV infection incidence and risk factors among 520 men who have sex with men in Guangzhou city. J Diagn Ther Dermato-Venereol. 2017;3:207-11.

353. Zhang W, Wu YD, Yao M. Analysis of epidemiological characteristics of male homosexual AIDS positive cases in Yunyan District of Guiyang City. Guizhou Medicine. 2016:40:991.

354. Sun CY, Yin SH, Sha L, et al. A survey on the infecton status of HIV, syphilis and HCV among male homosexual population in Mudanjiang. J Med Pest Control. 2017:33:229-30.
355. Guo W, Meng XJ, Li DM. Results of sentinel surveillance on men who have sex with men in Jilin province between 2010 and 2015. Chin J Epidemiol. 2017;38:1655-9.

356. Wang Y, Li LL, Fan J, Zhao XH. Analysis of current situation of HIV test and its influencing factors among men who have sex with men in Mianyang of China. Chin J Viral Dis. 2018;8:11-6.

357. Xu YY, Zhu ZP, Wu SS, et al. Guo Lu,Zhang Min infection status of HIV in men who have sex with men in Nanjing.2011-2015. Chin J Epidemiol. 2016; 37:1503-8.

358. Chi FL, Tao B, Yang JY, Qu L, Su L. Factors influencing HIV infection among MSM in Inner Mongolia. Pract Prev Med. 2018;25:219-22.

359. Zhu JQ, Zhou BB, MAO YB, et al. Survey on awareness of AIDS and infection status of HIVamong MSM in Yinzhou district. Chin J Hum. 2016;25:107-10.

360. Liu SC, Zhao J, Chen L, Tan W, Xie W. HIV incidence among men who have sex with men in Shenzhen, 2013- 2015. China Trop Med. 2017;17:774-7.

361. Dong $X Y$, Gong H, Bai JY. Analysis on the prevalence and influencing factors of HIV among men who have sex with men in Tianjin. Int J Virol. 2018;25: 327-33.

362. Ma L. Analysis of HIV infection and risk factors among MSM in Tongchuan. J Prev Med Inf. 2018;34:462-6.

363. Wei XD, Luo CX, He CY. Seroprevalence of HIV-1, syphilis and HSV-2 infections among MSM in Changsha City. Pract Prey Med. 2016;2:947-9.

364. Hu XW, Liu JN, Wu H, Wang H, Zheng L. Prevalence of HIV infection and related factors in men who have sex with men in Xihu district of Hangzhou. Dis Surveill. 2017:32:651-5.

365. Lin HT, Zhang YC, Shen WW. Investigation of group sex in men who have sex with men in Taizhou, Zhejiang province, 2013-2015. Chin J Epidemiol. 2017;38:634-7.

366. Lai $X H$, Chen $C Y$, Wang M, Sun YM. Epidemiological characteristics of HIV/ AIDS among MSM in Zhongshan city, 2012-2014. Chin J AID S STD. 2017;23: 254-7.

367. CDC. Prevalence and awareness of HIV infection among men who have sex with men- -- 21 cities, United States, 2008. MMWR Morb Mortal Wkly Rep. 2010;59:1201-7.

368. Beyrer C, Baral SD, van Griensven F, Goodreau SM, Chariyalertsak S, Wirtz AL, Brookmeyer R. Global epidemiology of HIV infection in men who have sex with men. Lancet. 2012;380:367-77.

369. Huang MB, Ye L, Liang BY, Ning CY, Roth WW, Jiang JJ, Huang JG, Zhou B, Zang N, Powell MD, Liang H, Bond VC. Characterizing the HIV/AIDS epidemic in the United States and China. Int J Environ Res Public Health. 2015;13:ijerph13010030.

370. Oster AM, Johnson CH, Le BC, Balaji AB, Finlayson TJ, Lansky A, Mermin J, Valleroy L, Mackellar D, Behel S, Paz-Bailey G. Trends in HIV prevalence and HIV testing among young MSM: five United States cities, 1994-2011. AIDS Behav. 2014;18(Suppl 3):S237-47.

371. Desai S, Croxford S, Brown AE, Mitchell H, Hughes G, Delpech V. An overview of the HIV epidemic among men who have sex with men in the United Kingdom, 1999-2013. Euro Surveill. 2015;20:1-8

372. Li YZ, Xu JJ, Qian HZ, You BX, Zhang J, Zhang JM, Hu QH, Chu ZX, Liu SY, Jiang YJ, Geng WQ, Shang H. High prevalence of HIV infection and unprotected anal intercourse among older men who have sex with men in China: a systematic review and meta-analysis. BMC Infect Dis. 2014;14:531.

373. Mansergh G, Marks G. Age and risk of HIV infection in men who have sex with men. AIDS. 1998;12:1119-28.

374. Yang Z, Huang Z, Dong Z, Zhang S, Han J, Jin M. Prevalence of high-risky behaviors in transmission of HIV among high school and college student MSM in China: a meta-analysis. BMC Public Health. 2015;15:1272.

375. Mansergh G, Purcell DW, Stall R, McFarlane M, Semaan S, Valentine J, Valdiserri R. CDC consultation on methamphetamine use and sexual risk behavior for HIV/STD infection: summary and suggestions. Public Health Rep. 2006;121:127-32

376. Stall R, Paul JP, Greenwood G, Pollack LM, Bein E, Crosby GM, Mills TC, Binson D, Coates TJ, Catania JA. Alcohol use, drug use and alcohol-related problems among men who have sex with men: the urban Men's health study. Addiction. 2001;96:1589-601

377. Thornton A, Lee P. Publication bias in meta-analysis: its causes and consequences. J Clin Epidemiol. 2000;53:207-16.

378. Liberati A, Altman DG, Tetzlaff J, Mulrow C, Gøtzsche PC, loannidis JP, Clarke M, Devereaux PJ, Kleijnen J, Moher D. The PRISMA statement for reporting systematic reviews and meta-analyses of studies that evaluate health care interventions: explanation and elaboration. J Clin Epidemiol. 2009;62:e1-e34. 
379. Wong WC, Cheung CS, Hart GJ. Development of a quality assessment tool for systematic reviews ofobservational studies (QATSO) of HIV prevalence in men having sex with men and associated risk behaviours. Emerg Themes Epidemiol. 2008:5:23.

380. Higgins JP, Thompson SG, Deeks JJ, Altman DG. Measuring inconsistency in meta-analyses. BMJ. 2003;327:557-60

381. R Core Team. R. A language and environment for statistical computing. Version 3.2.3. (R Foundation for Statistical Computing: Vienna), 2015.

382. Horton KC, MacPherson P, Houben RM, White RG, Corbett EL. Sex differences in tuberculosis burden and notifications in low-and middleincome countries: a systematic review and meta-analysis. PLoS Med. 2016; 13:e1002119.

\section{Publisher's Note}

Springer Nature remains neutral with regard to jurisdictional claims in published maps and institutional affiliations.

Ready to submit your research? Choose BMC and benefit from:

- fast, convenient online submission

- thorough peer review by experienced researchers in your field

- rapid publication on acceptance

- support for research data, including large and complex data types

- gold Open Access which fosters wider collaboration and increased citations

- maximum visibility for your research: over $100 \mathrm{M}$ website views per year

At $B M C$, research is always in progress.

Learn more biomedcentral.com/submissions 